\title{
MC3644 Detonator Development Status Report for the Period Ending October 30, 1981
}

Albin K. Jacobson

Prepared by

Sandia National Laboratories

Albuquerque, New Mexico 87185 and Livermore, California 94550

for the United States Department of Energy

under Contract DE-AC04-76DP00789

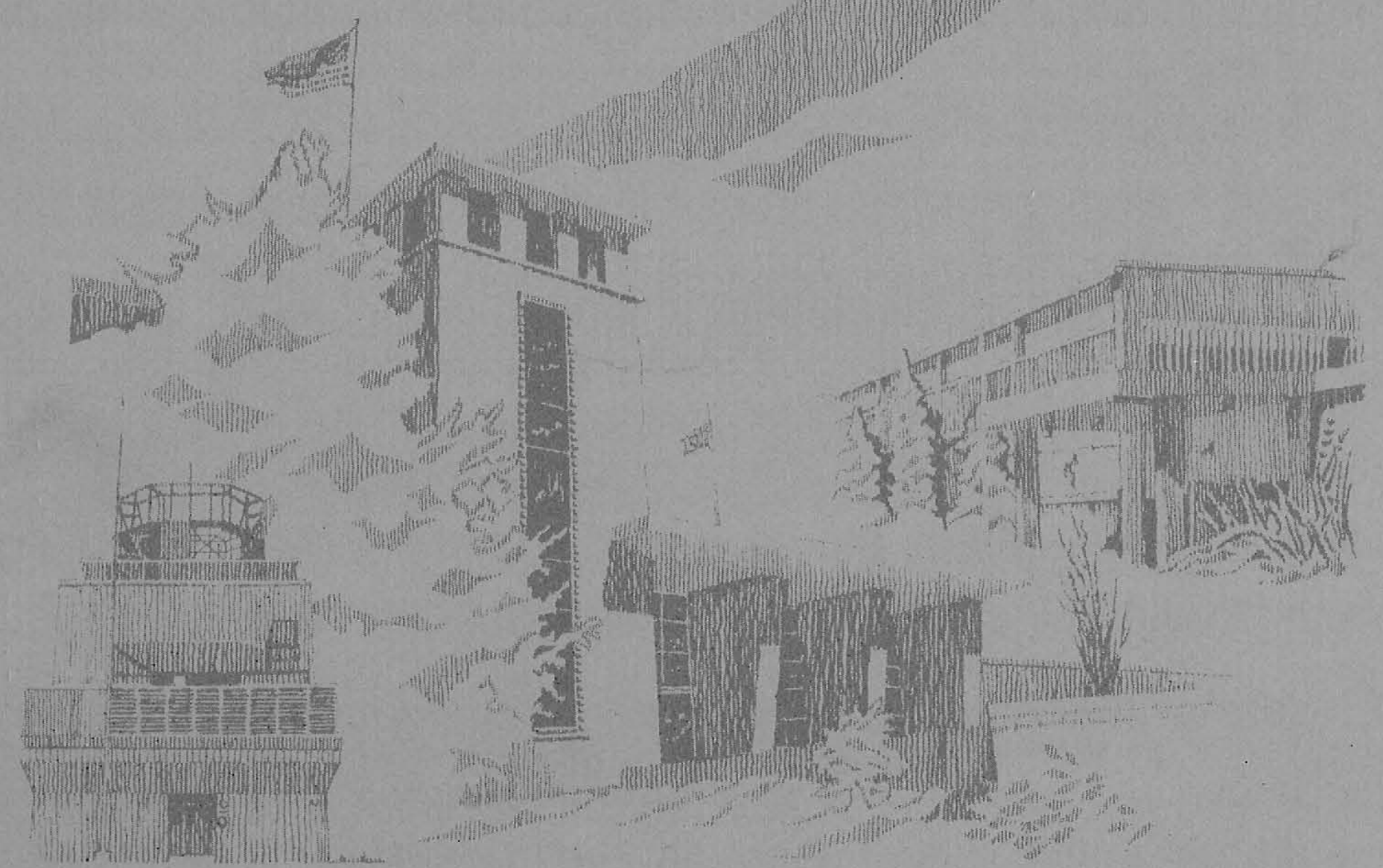




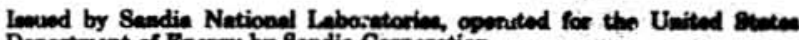
Department $\alpha$ Benry by Sendia Corporation.

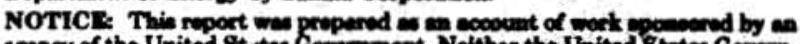

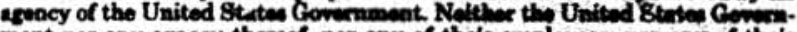

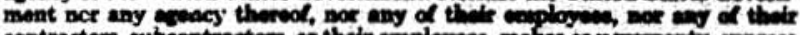

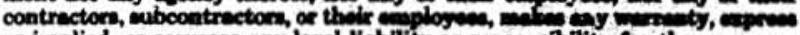

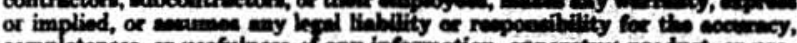

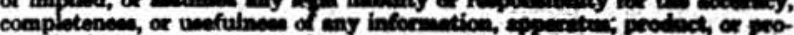

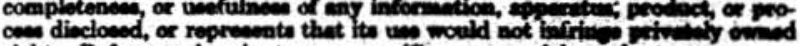

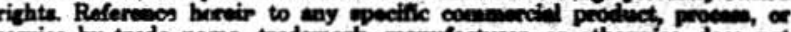

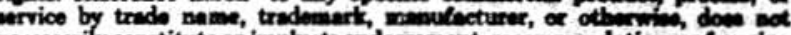

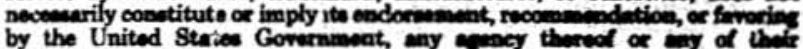
contractors of subeontractom. Tho vien and oplaiones oupremed burvin do not necesearily ateits at reflect thow of the United Steten Gomernment, any agency thereof of any of their contraction of wabcontractors.

Printed in the United States of America Available from

National Technical Information Service

U.S. Department of Commerce

5285 Port Royel Roed

Springfield, Vi 22161

NTIS price codes

Microfiche copy: $\mathrm{A} 0$ 


\title{
MC3644 Detonator Development Status Report for the Period Ending October 30, 1981
}

Albin K. Jacobson

Detonating Components Division 2513

Sandia National Laboratories

Albuquerque, NM 87185

\begin{abstract}
The MC3644 detonator is being developed as a replacement for the MC3132 flying plate detonator in the parachute deployment system of the B83 weapon. The MC3644 is a CP, deflagration-to-detonation transition device. Two models are being developed: an interim design using the MC3423 ignitor and a new production version with a onepiece ignitor/header assembly. Features of both designs are described. Results of development tests involving the interim design are presented. No-fire sensitivity test and proof-test results with the WR version are also included. The development program is on schedule.
\end{abstract}




\section{Acknowledgments}

The author thanks M. L. Lieberman and F. J. Villa, (2515); J. E. Kennedy, J. G. Harlan, and R. J. Burnett (2513); and A. C. Schwarz (2515); all of Sandia National Laboratories; W. R. Henderson and E. E. Tibbitts of Mound Facility; R. DeCoursey of Unidynamics/Phoenix, Inc; and G. Seavy of VRLER, Inc for their technical input and support during MC3644 development and in the preparation of this report. 


\section{Contents}

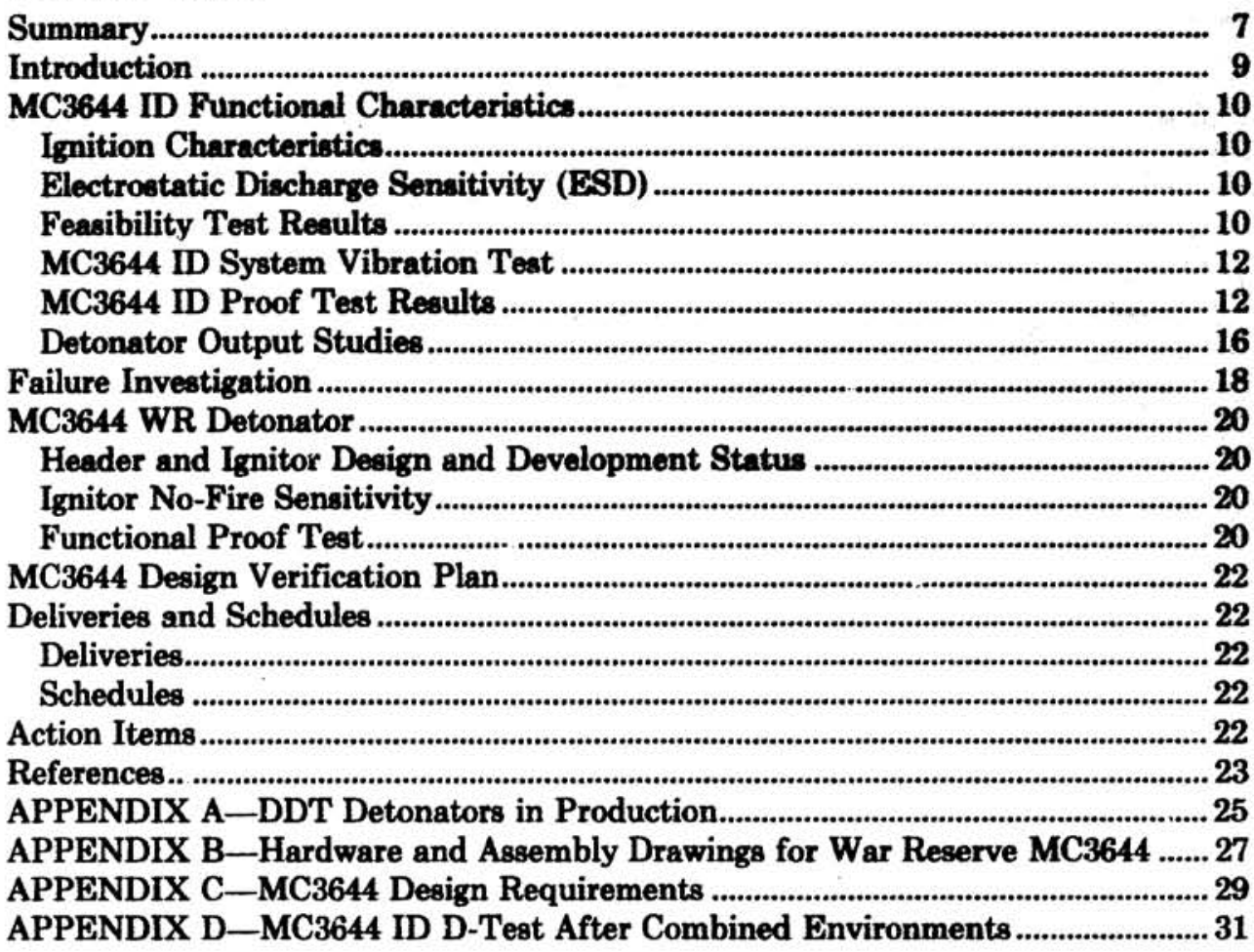

\section{Figures}

1 Typical MC3644/HNS-IIA ALMDF Assembly .................................................. 9

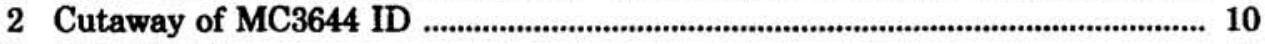

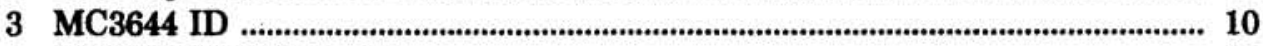

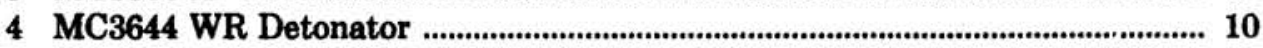

5 Test Fixture Assembly ..................................................................................... 11

6 Assembly for Closure-Disc Velocity Measurement .............................................. 16

7 Typical Closure-Disc Velocity and Displacement Histories ................................ 17

8 Closure-Disc Velocity and Displacement Histories for MC3644 WR Detonator With 0.13-mm-Thick Disc ....................................... 17

9 Comparison of Fired and Failed MC3644 ID Detonators .................................. 19

10 No-Fire Probability Curves for MC3644 .......................................................... 21

11 MC3644 ID Function Time as a Function of Gamma ...................................... 22

12 MC3644 WR Function Time as a Function of Gamma .................................... 22

13 MC3644 WR Development and Phase IV Production Schedules .................... 23

\section{Tables}

1 ETR Data Summary of MC3644 ID Feasibility Tests ...................................... 11

2 MC3644 ID Feasibility Test-Fire Results ......................................................... 11

3 Electrothermal Response Data for MC3644 ID System Random Vibration Tests ........................................................................................................ 12

4 Static Deployment Test Results ............................................................................ 13 


\section{Tables (cont)}

5 MC3644 ID Combined Environment Test Series Eloctrothermal Response Data

6 Summary of MC3644 Proof Test Data After Combined Environments

7 Summary of MC3644 ID Electrothermal Response Data 14

8 Bridgewire Resistance History of Unit 108

9 Output Charge Parameters and Closure Disc Velocity Data at

Room Temperature

10 MC3644 ID Failure Analysis Test Data ..

19

11 Electrothermal Response Test Results on Development Lot A of MC3644 WR Detonator

12 Prethermal and Postthermal Shock Electrothermal Response Data for MC3644 WR Functional Proof Test .................................................................. 21

13 MC3644 WR Proof Test Data ................................................................................ 21 


\section{Summary}

Development of the MC3644 Interim Detonator (ID) at Unidynamics/Phoenix, Inc (UPI) is complete. Fifty detonators were shipped to Sandia National Laboratories, Albuquerque (SNLA) for use in the B83 Parachute Deployment System (PDS) development. Of the 50, 6 were successfully tested at the system level; 34 additional MC3644 IDs were tested at UPI. One detonator failed to detonate. The investigation into the cause of the failure has not been completed; however, it appears that a defective header may have caused the failure. Of the 34 detonators tested at UPI, 15 were tested after being subjected to a combined series of mechanical and thermal environments. There were no failures in this group of units.

Functional proof testing of the War Reserve (WR) final design MC3644 was successfully completed at UPI. Ten WR MC3644s and six trainers were shipped to SNLA. No-fire sensitivity tests verified that the 1.0-A requirement is met.

The action items related to the MC3644 development program are described at the end of this report. 


\section{MC3644 Detonator Development Status Report for the Period Ending October 30, 1981}

\section{Introduction}

The MC3644 detonator (part number 318493) is being developed for use in the Parachute Deployment System (PDS) of the B83 weapon. The axial detonator output will side-initiate 10 -grains/ft hexanitrostilbene aluminum-sheath mild detonating fuze (HNS-IIA ALMDF). ${ }^{1}$ The force generated by the detonating HNS-IIA ALMDF ejects the deployment cover assembly that, in turn, deploys the B83 parachute. Two MC3644s will be used in each weapon. A typical detonator/mild detonating fuse (MDF) assembly is illustrated in Figure 1. The MC3644 development activities are being conducted at Sandia National Laboratories, Albuquerque (SNLA) and at UPI under Contract 61-3840

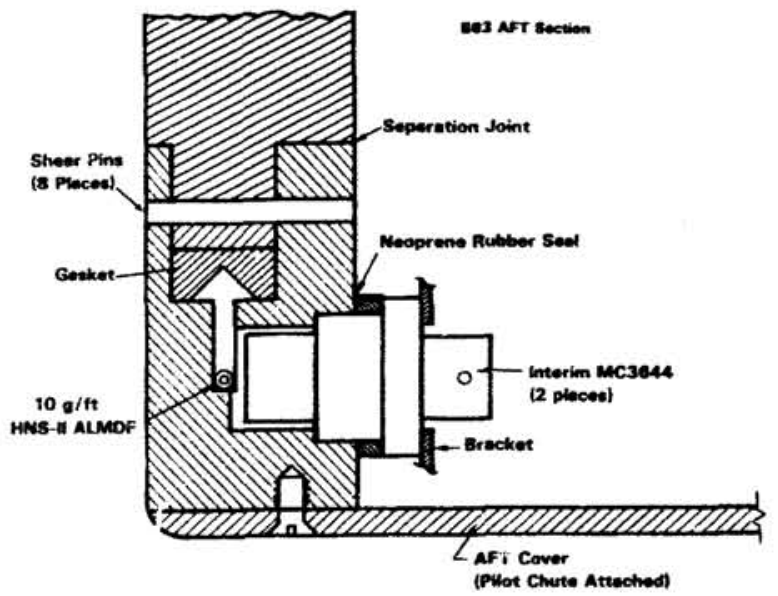

Figure 1. Typical MC3644/HNS-IIA ALMDF Assembly

The MC3644 is a deflagration-to-detonation transition (DDT) detonator using the explosive 2-(5-cyanotetrazolato) pentaamminecobalt (III) perchlorate, which is designated CP. The synthesis, ${ }^{2}$ explosive properties, ${ }^{3}$ thermal capabilitios, ${ }^{4}$ ignition, and electrostatıc sensitivity characteriatics have been reported in relation to the development of other DDT components. A list of these components is provided in Appendix A. A list of reports and resources are included in Reference 4.

Two versions of the MC3644 are being developed in parallel activities. The development testing of an interim design (Figures 2 and 3) was completed at UPI. This version will be used in parachute development testing until the war reserve (WR) version becomes available. The interim design consists of three subassemblies. The output subassembly, which is common to both versions, includes the DDT and output charges. The 6.2-mm-long DDT column consists of $0.272 \mathrm{~g}$ of CP pressed in four equal increments to a density of $1.5 \mathrm{Mg} / \mathrm{m}^{3}$. Two increments of CP $\left(0.037 \mathrm{~g}\right.$ total) are pressed to a density of $1.75 \mathrm{Mg} / \mathrm{m}^{3}$ in the output pellet. The output pellet length is 2.54 $\mathrm{mm}$. The ignitor used in the interim MC3644 is in production at UPI for the MC3423 detonator. ${ }^{5}$ The proven functional characteristics of this ignitor meet the requirements of the $\mathrm{B} 83$ program. The ignitor is laser-welded into the output subassembly. The electrical header is used to adapt the ignitor pigtail leuds to the SA2052 connector on the system electrical cable. The pins in the electrical header are hollow and act as the receptacle for the ignitor leads. The leads are soldered to the header pins. Four laser welds are required to complete the assembly.

The WR version (Figure 4) is discussed later in this report. A list of drawings defining the MC3644 WR is included in Appendix B. The design requirements are included in Appendix C. 


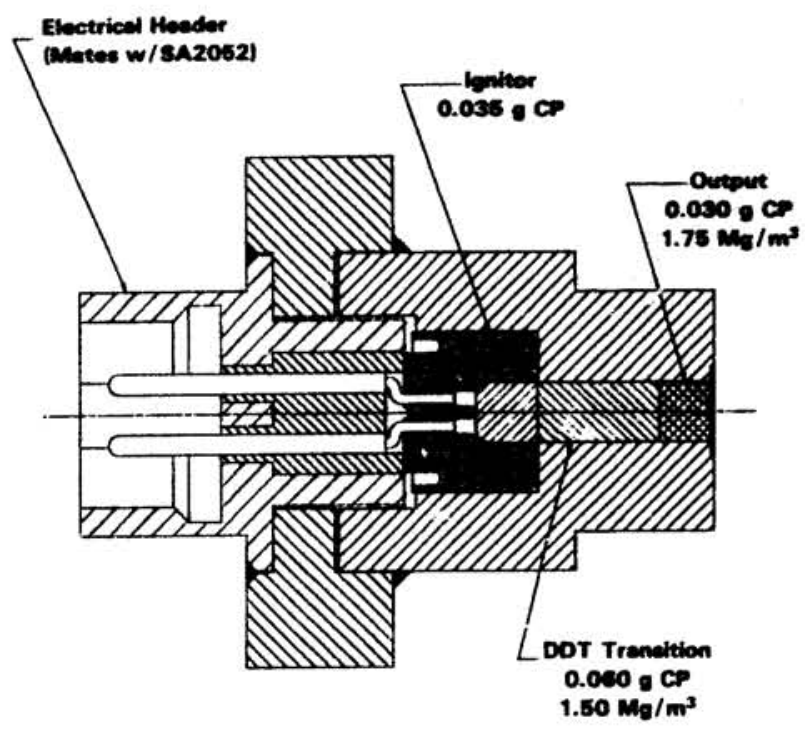

Figure 2. Cutaway of MC3644 ID

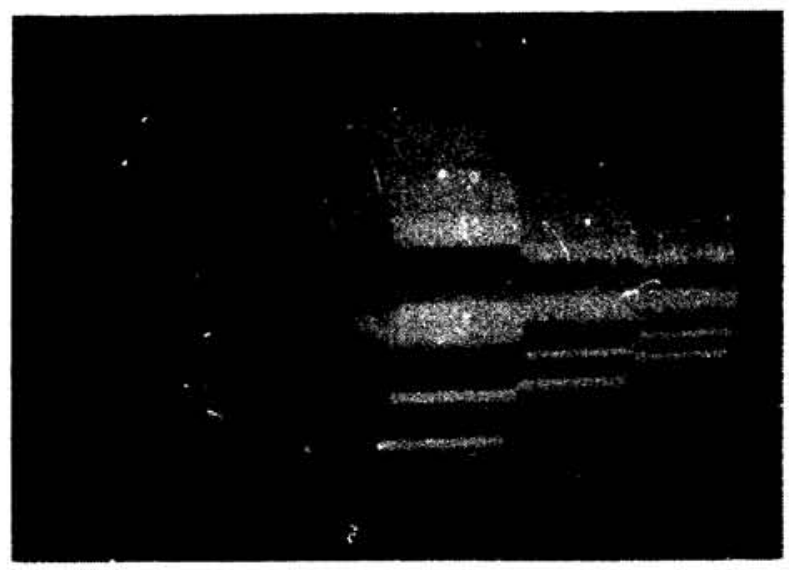

Figure 3. MC3644 ID

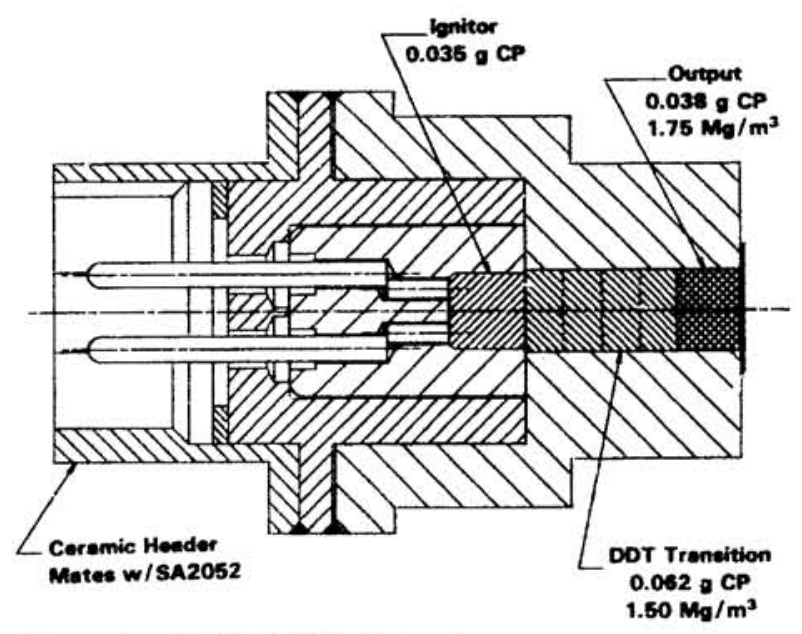

Figure 4. MC3644 WR Detonator

\section{MC3644 ID Functional Characteristics}

The ignition and safety characteristios of the MC3644 ID were demonstrated in the development of the MC3423 detonator. 5 The combined ignitor and output characteristics were tested as part of the MC3644 ID development effort.

\section{Ignition Characteristics}

The MC3644 ID ignitor (MC3423) has a single 0.051-mm-diameter Tophet $\mathrm{A}$ bridgewire resiatance welded to 1.02-mm-diameter Kovar pins. The pin spacing is $1.40 \mathrm{~mm}$. The wire is looped to achieve sufficient length for a 1.0-ohm bridgewire. Two 18-mg increments of CP are pressed onto the wire at a density of $1.75 \mathrm{Mg} / \mathrm{m}^{3}$ at $276 \mathrm{MPa}$.

The all-fire and no-fire characteristics for this design were determined by forty-unit Bruceton sensitivity tests run at $-54^{\circ} \mathrm{C}$ and ambient temperature, respectively. ${ }^{8}$ The resulting reliability statements are summarized below.

\section{All-Fire at $-54^{\circ} \mathrm{C}$}

Fifty-percent threshold: $2.21 \mathrm{~A}$ with a standard deviation of $0.038 \mathrm{~A}$.

Ninety-five-percent confidence statement: 999 in 1000 will fire at $2.41 \mathrm{~A}$.

\section{No-Fire at Ambient Temperature}

Fifty-percent threshold: $1.46 \mathrm{~A}$ with a standard deviation of $0.064 \mathrm{~A}$.

Ninety-five-percent confidence statement: only 1 in 1000 will fire at $1.14 \mathrm{~A}$.

\section{Electrostatic Discharge Sensitivity (ESD)}

ESD protection for the MC3644 ID is achieved through the use of a $0.25-\mathrm{mm}$-wide spark gap between the electrical leads and the case of the ignitor. Development ESD test results for the MC3423 have been reported. ${ }^{7}$ Over 200 loaded ignitors were tested without a firing to the $20-\mathrm{kV} 600$-pf 500 -ohm requirement.

\section{Feasibility Test Results}

The feasibility of using a CP-DDT detonator to initiate the HNS-IIA ALMDF in the B83 application was demonstrated at UPI in a series of test firings at $-55^{\circ} \mathrm{C}$, ambient, and $130^{\circ} \mathrm{C}$. Ten MC3644 IDs were fabricated and assembled with HNS-IIA ALMDF into 
test fixtures designed to simulate the B83 hardware configuration (Figure 5). The deaign includes a 1.3mm air gap between the detonator and the HNS-IIA ALMDF. Three assemblies were conditioned at each of the three temperatures for a minimum of $2 \mathrm{~h}$. One detonator has not been teated.

The electrothermal response (ETR) data for the group of detonators are summarized in Table 1. Test fire results at each temperature are given in Table 2. The test current was $5.0 \mathrm{~A}$ from a constant current source.

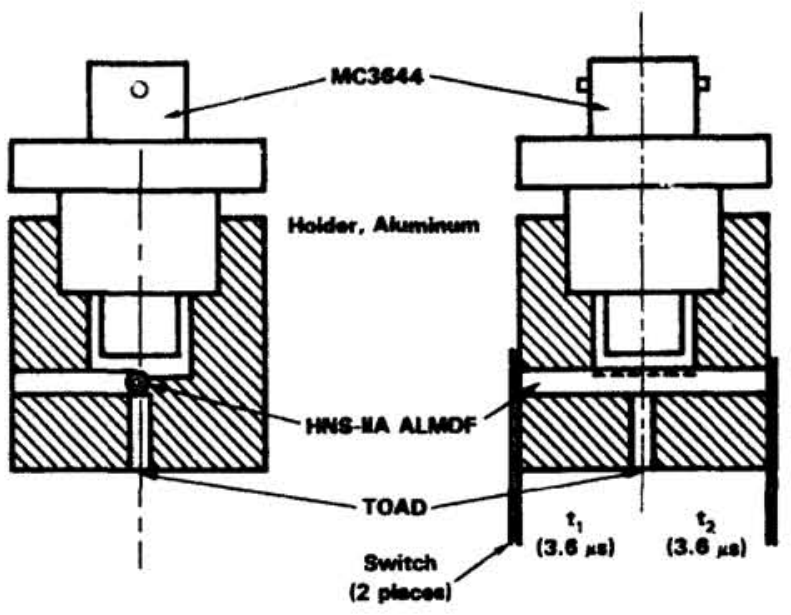

The ignition time $(t)$ shown in Table 2 wes celenlated from bridgewire current and voltep with the ves of the Calculator Controlled Data Syitem (CCDS)" UA1538 at UPI. The calculation is bead on a bridgewire thermal model which reaponds to e drop in voltage which typically occurs at ignition of the explosive pressed on the bridgewire.

In this group of teats, the apparent ignition time is longer than the detonator function time. Two pouible explanations are that the incorrect program was und or that the model is not sensitive enough to the eudden changes in bridgewire reaistance which typically occur at ignition of the explosive. This numerical anomaly is being investigated.

Table 1. ETR Data Summary of ucse44 id Feasibility Teats

Bare Loeded Final Bridgewire Ignitor Aseembly

\begin{tabular}{lcrr}
\hline Average $\left(\mu \mathrm{W} /{ }^{\circ} \mathrm{C}\right)$ & 690.4 & 15340 & 15040 \\
Standard deviation $\left(\mu \mathrm{W} /{ }^{\rho} \mathrm{C}\right)$ & 21.8 & 989 & 1909 \\
Range $\left(\mu \mathrm{W} /{ }^{\circ} \mathrm{C}\right)$ & 67 & 3444 & 5821 \\
Number tested & 10 & 10 & 10
\end{tabular}

Figure 5. Test Fixture Assembly

\section{Table 2. MC3644 ID Feaslbility Test-Fire Results}

\begin{tabular}{ccccccccc} 
Shot & $\begin{array}{c}\text { Temp. } \\
\left({ }^{\circ} \mathrm{C}\right)\end{array}$ & $\begin{array}{c}\text { Serial } \\
\text { No. }\end{array}$ & $\begin{array}{c}\text { Ignition } \\
\text { Time }\left(\mathrm{t}_{\mathrm{i}}\right) \\
(\mu \mathrm{s})\end{array}$ & $\begin{array}{c}\text { Bridgewire } \\
\text { Open } \\
(\mu \mathrm{s})\end{array}$ & $\begin{array}{c}\text { Function } \\
\text { Time } \\
(\mu \mathrm{s})\end{array}$ & $\begin{array}{c}\mathrm{t}_{1}{ }^{*} \\
(\mu \mathrm{s})\end{array}$ & $\begin{array}{c}\mathrm{t}_{2}{ }^{*} \\
(\mu \mathrm{s})\end{array}$ & $\begin{array}{c}\text { Gamma** } \\
(\mu \mathrm{W} / \mathrm{K})\end{array}$ \\
\hline 1 & Ambient & 19 & - & - & 621 & 6.8 & 7.6 & 15000 \\
2 & Ambient & 16 & 660 & 700 & 641 & 7.2 & 7.2 & 16000 \\
3 & Ambient & 11 & 640 & 680 & 627 & 7.0 & 7.1 & $\mathbf{1 6 0 0 0}$ \\
4 & -55 & 10 & 750 & 780 & 731 & 7.2 & 7.2 & 17000 \\
5 & -55 & 12 & 730 & 770 & 711 & 7.1 & 7.1 & 16000 \\
$6 \dagger$ & -55 & 14 & 730 & 770 & 702 & - & - & 10000 \\
7 & 130 & 13 & 550 & 580 & $\mathbf{5 2 9}$ & 7.2 & 7.1 & 15000 \\
8 & 130 & 11 & 550 & 590 & 526 & 7.2 & 7.2 & 15000 \\
9 & 130 & 15 & 550 & 600 & 527 & 7.2 & 8.5 & 13000
\end{tabular}

*Transit time in HNS-IIA ALMDF

**Gamma after temperature conditioning

†No MDF detonation 
The times $t_{1}$ and $t_{2}$ are the elapeed time from shock arrival at the time-of-arrival detector (TOAD) (Figure 5) to the arrival of the detonation wave at the end of the HNS-IIA ALMDF. This was the first attempt to measure detonation transit time in the HNS-IIA ALMDF after impact of the detonator closure disc. The program goal is to initiate a length of HNS-IIA ALMDF with each MC3644 tested. Once the technique is developed, the times $t_{1}$ and $t_{2}$ should give an indication of how uniformly the detonation is developing in the side-initiated HNS-IIA ALMDF.

The transit time has been calculated using a velocity of detonation for HNS-IIA ALMDF of $6.5 \mathrm{~km} / \mathrm{g}$ and a shock velocity in aluminum of $6.0 \mathrm{~km} / \mathrm{s}$. For the purpose of this calculation, it was assumed that detontion occurred immediately inside the aluminum sheath, i.e., zero run distance to detonation, and that it occurred either on the detonator axis or at the edge of the closure disc. The calculated transit time, is 7.11 to $7.52 \mu \mathrm{s}$, depending on the origin of detonation, and taking into account the transit time from point of detonation to the TOAD.

With the exception of Shot 6, the HNS-IIA ALMDF detonated in each shot. An aluminum witness block was used to determine if the HNS-IIA ALMDF detonated. Additional evaluation of this technique will be required before a specification can be established and before the 8.5- $\mu$ s time in Shot 9 should be considered a problem.

It has been determined that the $\mathrm{CP}$ in detonator 14 (Shot 6) failed to grow to detonation. The investigation into this failure is discussed later in this report.

\section{MC3644 ID System Vibration Test}

Two deployment covers with two MC3644 IDs each were subjected at room temperature to a simulated sled-track random-vibration environment. The sled-track environment is an overtest for the system, but it was used because some parachute testing is done on the sled track. Subsequent to vibration, the deployment covers were assembled to a static test stand and fired. The deployment velocity of each cover was measured. The fire-pulse current was applied to only one detonator in each test. In test 1 , the second feicuator was sympathetically initiated by the HNSlis ALMDF. The second detonator in test 2 (unit 61, Shot 3 , Table 2) was removed from the cover and tested in a separate fixture. A short length of HNS-IIA ALMDF was initiated successfully, but an instrumentation problem erased the data.

ETR measurements were made on each detonator before and after vibration. The data are given in Table 3. Units 28 and 56 were subjected to two cycles of vibration. Deployment teat results are shown in Tablo 4. The range in gamma is larger than one would expect and is probably due to differences in the unit anembly procedures.

\section{MC3644 ID Proof Teet Recults}

Fifteen MC3644 IDs were asembled and subjected to the combined environments of thermal shock, mechanical shock, and vibration (Appendix C) as outlined in PS318493 Issue A. The units were subjected to the mechanical shock and vibration environments at room temperature. The units were fired in the fixtures shown in Figure 5. The effect of the environments on the CP/bridgewire interface as determined by ETR testing is summarized in Table 5. The destructive test data are summarized in Table 6. The raw teat data are included in Appendix D. The times $t_{1}$ and $t_{2}$ in Table 6 are the elapeed times from TOAD output to switch closure at each end of the HNS-IIA ALMDF (Figure 5). With one exception, the data in channel $2\left(t_{2}\right)$ average 17 ns longer. This characteristic has persisted since the start of the program. The cause remains to be determined. The HNSIIA ALMDF has fired satisfactorily in 29 MC3644 ID tests at UPI.

A summary of ETR data at each assembly step is included in Table 7. ETR measurements were made of two small group of detonators (serial nos. 70-79 and $90-107)$ to determine if the final assembly weld of the connector and the soldering of the connector pins affected the unit quality. The limited data indicate there is no effect.

Table 3. Electrothermal Response Data for MC3644 ID System Random Vibration Tests

\begin{tabular}{|c|c|c|c|c|}
\hline \multirow[b]{2}{*}{$\begin{array}{c}\text { Serial } \\
\text { No. }\end{array}$} & \multicolumn{4}{|c|}{$\operatorname{Gamma}\left(\mu \mathrm{W} /{ }^{\circ} \mathrm{C}\right)$} \\
\hline & $\begin{array}{c}\text { Ignitor } \\
\text { Only } \\
\end{array}$ & $\begin{array}{l}\text { After } \\
\text { Weld } \\
\end{array}$ & $\begin{array}{c}\text { After } \\
\text { Shipping }\end{array}$ & $\begin{array}{c}\text { After } \\
\text { Vibration }\end{array}$ \\
\hline 18 & 14,000 & 16,000 & 15,000 & 15,000 \\
\hline 28 & 13,000 & 13,000 & 14,000 & 12,000 \\
\hline 56 & 10,000 & 10,000 & 10,000 & 10,000 \\
\hline 61 & 9,000 & 9,000 & 9,000 & 9,000 \\
\hline Average & 12,000 & 12,000 & 12,000 & 12,000 \\
\hline $\begin{array}{l}\text { Standard } \\
\text { Deviation }\end{array}$ & 3,000 & 3,000 & 3,000 & 2,000 \\
\hline
\end{tabular}




\section{Table 4. Static Deployment Test Results}

\begin{tabular}{|c|c|c|c|c|c|c|c|}
\hline Shot & Unit & $\begin{array}{l}\text { Bridgewire } \\
\text { Resistance } \\
\text { at Ignition } \\
\text { (cI.ms) }\end{array}$ & $\begin{array}{c}\text { Ignition } \\
\text { Time ( } \mu \mathrm{s}) \\
\end{array}$ & $\begin{array}{c}\text { BW } \\
\text { Gpen } \\
(\mu \mathrm{s}) \\
\end{array}$ & $\begin{array}{c}\text { Ignition } \\
\text { Energy (mJ) }\end{array}$ & 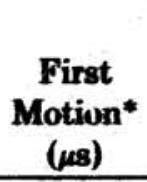 & $\begin{array}{c}\text { Cover } \\
\text { Velocity } \\
(\mathrm{m} / \mathrm{s})\end{array}$ \\
\hline 1 & 56 & 1.07 & . 600 & 640 & 13.6 & $860 / 810$ & 23.8 \\
\hline 2 & 18 & 1.03 & 640 & 700 & 15.9 & $980 / 860$ & 21.3 \\
\hline 3 & 61 & ND & ND & ND & & & \\
\hline
\end{tabular}

"First motion is the elapsed time from the leading edge of the fire pulse to the time the shear pins retaining the cover began to shear. The times recorded were monitored $180^{\circ}$ apart, adjacent to the detonator mounting holes. The early time was recorded adjacent to the fired detonator.

Table 5. MC3644 ID Combined Environment Test Series Electrothermal Response Data

\begin{tabular}{|c|c|c|c|c|}
\hline & $\begin{array}{c}\text { Before } \\
\text { Environment }\end{array}$ & $\begin{array}{l}\text { After Thermal } \\
\text { Shock }\end{array}$ & $\begin{array}{l}\text { After Mechanical } \\
\text { Shock }\end{array}$ & $\begin{array}{c}\text { After } \\
\text { Vibration }\end{array}$ \\
\hline $\begin{array}{l}\text { Number of units } \\
\text { Gamma }\left(\mu \mathrm{W} /{ }^{\circ} \mathrm{C}\right)\end{array}$ & \multicolumn{4}{|c|}{$\operatorname{Gamma}^{*}\left(\mu \mathrm{W} /{ }^{\circ} \mathrm{C}\right)$} \\
\hline Average & 17000 & 16000 & 15000 & 15000 \\
\hline Standard Deviation & 3000 & 2000 & 3000 & 3000 \\
\hline Minimum & 10000 & 12000 & 9000 & 9000 \\
\hline Maximum & 22000 & 20000 & 19000 & 19000 \\
\hline \multicolumn{5}{|c|}{ Bridgewire Resistance (ohm) } \\
\hline Average & 1.004 & 1.092 & 1.053 & 1.051 \\
\hline Standard Deviation & 0.024 & 0.04 & 0.023 & 0.021 \\
\hline Minimum & 0.971 & 1.035 & 1.011 & 1.008 \\
\hline Maximum & 1.048 & 1.204 & 1.113 & 1.091 \\
\hline \multicolumn{5}{|l|}{ Theta $\left({ }^{\circ} \mathrm{C}\right)$} \\
\hline Average & 29.9 & 35.0 & 36.9 & 36.7 \\
\hline Standard Deviation & 7.8 & 5.9 & 8.6 & 8.6 \\
\hline Minimum & 22.2 & 26.4 & 27.3 & 26.8 \\
\hline Maximum & 49.8 & 47.0 & 58.5 & 59.3 \\
\hline
\end{tabular}

*Values are rounded off to be consistent with an expected error of approximately 800 in standard deviation. 


\section{Table 6. Summary of MCse44 Proof Toet Data After Combined}

\section{Environmente}

\begin{tabular}{|c|c|c|c|c|c|c|c|c|}
\hline $\begin{array}{c}\text { Number of } \\
\text { Units }\end{array}$ & $\begin{array}{c}\text { Test } \\
\text { Temperature } \\
\end{array}$ & $\begin{array}{c}t_{1} \\
(\mu s)\end{array}$ & $\begin{array}{c}\mathrm{E}_{4} \\
(\mathbf{m J})\end{array}$ & $\begin{array}{c}t \\
(\mu / 4)\end{array}$ & $\begin{array}{c}4 \\
\text { (us) }\end{array}$ & $\begin{array}{c}\mathbf{R}_{\mathbf{1}} \\
\text { (ohm) }\end{array}$ & $\begin{array}{c}t_{1} \\
(\mu)\end{array}$ & $\begin{array}{c}h_{2} \\
(m)\end{array}$ \\
\hline 5 & $\begin{array}{l}\text { Ambient } \\
\text { Average } \\
\text { Standard Dev. }\end{array}$ & $\begin{array}{r}628 \\
50\end{array}$ & $\begin{array}{c}15.8 \\
0.76\end{array}$ & $\begin{array}{r}752 \\
82\end{array}$ & $\begin{array}{r}624 \\
46\end{array}$ & $\begin{array}{l}1.15 \\
0.05\end{array}$ & $\begin{array}{l}6.84 \\
0.07\end{array}$ & $\begin{array}{l}7.01 \\
0.07\end{array}$ \\
\hline 5 & $\begin{array}{l}-55^{\circ} \mathrm{C} \\
\text { Average } \\
\text { Standard Dev. }\end{array}$ & $\begin{array}{r}760 \\
87\end{array}$ & $\begin{array}{r}19.9 \\
2.2\end{array}$ & $\begin{array}{r}1404 \\
646\end{array}$ & $\begin{array}{r}757 \\
86\end{array}$ & $\begin{array}{l}1.19 \\
0.02\end{array}$ & $\begin{array}{l}6.82 \\
0.07\end{array}$ & $\begin{array}{l}7.11 \\
0.03\end{array}$ \\
\hline 5 & $\begin{array}{l}132^{\circ} \mathrm{C} \\
\text { Average } \\
\text { Standard Dev. } \\
\text { Ambient Control }\end{array}$ & $\begin{array}{r}522 \\
35\end{array}$ & $\begin{array}{c}14.2 \\
1.17\end{array}$ & $\begin{array}{l}900 \\
403\end{array}$ & $\begin{array}{r}525 \\
40\end{array}$ & $\begin{array}{l}1.22 \\
0.03\end{array}$ & $\begin{array}{l}7.00 \\
0.23\end{array}$ & $\begin{array}{l}7.06 \\
0.12\end{array}$ \\
\hline & $\begin{array}{l}\text { Average } \\
\text { Standard Dev. }\end{array}$ & $\begin{array}{c}588 \\
8.4\end{array}$ & $\begin{array}{c}15.2 \\
0.21\end{array}$ & $\begin{array}{l}882 \\
205\end{array}$ & $\begin{array}{l}584 \\
15.2\end{array}$ & $\begin{array}{l}1.17 \\
0.02\end{array}$ & $\begin{array}{l}6.91 \\
0.07\end{array}$ & $\begin{array}{l}7.12 \\
0.05\end{array}$ \\
\hline $\begin{array}{l}\text { Notes: } \\
\qquad \begin{aligned} t_{i} & = \\
E_{i} & = \\
t_{b} & = \\
t_{i} & = \\
R_{i} & = \\
t_{1} \text { and } t_{2} & =\end{aligned}\end{array}$ & $\begin{array}{l}\text { Ignition time } \\
\text { Ignition energy } \\
\text { Bridgewire break } \\
\text { Function time: lea } \\
\text { Bridgewire resista } \\
\text { Transit times in } \mathrm{H}\end{array}$ & $\begin{array}{l}\text { me } \\
\text { ing ed } \\
\text { ce at i } \\
\text { NS-IIA }\end{array}$ & $\begin{array}{l}\text { of pu } \\
\text { iition } \\
\text { ALMD }\end{array}$ & e to & D & put & & \\
\hline
\end{tabular}


Table 7. Summary of Mcse44 iD Electrothermal Response Data

\begin{tabular}{|c|c|c|c|c|}
\hline Item Teated & $\begin{array}{c}\text { Group } \\
\text { Serial } \\
\text { Numbar }\end{array}$ & $\begin{array}{c}\mathbf{R}_{0} \\
\text { (ohm) }\end{array}$ & $\begin{array}{c}\text { Thete } \\
\left.\text { ( }{ }^{\circ} \mathrm{C}\right)\end{array}$ & $\begin{array}{l}\text { Gamma } \\
\left(\mathrm{WW} /{ }^{\circ} \mathrm{C}\right)\end{array}$ \\
\hline Bare Bridgewire & $10-38$ & & & \\
\hline Mean & & 1.040 & 86.9 & 680 \\
\hline Minimum & & 0.971 & 86.5 & 500 \\
\hline Maximum & & 1.089 & 109.0 & 760 \\
\hline Standard Dev. & & 0.038 & 6.5 & 40 \\
\hline Number Teated & & 29 & 29 & 29 \\
\hline Bare Bridgewire & $39-98$ & & & \\
\hline Mean & & 0.954 & 97.6 & 620 \\
\hline Minimum & & 0.864 & 73.0 & 530 \\
\hline Maximum & & 1.052 & 125.6 & 800 \\
\hline Standard Dev. & & 0.045 & 9.1 & 60 \\
\hline Number Tested & & 60 & 60 & 60 \\
\hline Bare Bridgewire & 99-137 & & & \\
\hline Mean & & 0.994 & 97.6 & 660 \\
\hline Minimum & & 0.926 & 77.0 & 530 \\
\hline Maximum & & 1.027 & 121.2 & 810 \\
\hline Standard Dev. & & 0.025 & 11.0 & 70 \\
\hline Number Tested & & 39 & 39. & 39 \\
\hline Loaded Ignitor & $10-38$ & & & \\
\hline Mean & & 1.011 & 23.9 & 15300 \\
\hline Minimum & & 0.939 & 20.6 & 13300 \\
\hline Maximum & & 1.064 & $27 . ?$ & 16900 \\
\hline Standard Dev. & & 0.038 & 1.6 & 1100 \\
\hline Number Tested & & 29 & 29 & 29 \\
\hline Loaded Ignitor & 25-37 & & & \\
\hline Mean & & 1.022 & 26.0 & 14200 \\
\hline Minimum & & 0.965 & 23.9 & 12700 \\
\hline Maximum & & 1.075 & 28.2 & 15900 \\
\hline Standard Dev. & & 0.033 & 1.7 & 1100 \\
\hline Number Tested & & 12 & 12 & 12 \\
\hline Loaded Ignitor & $30-98$ & & & \\
\hline Mean & & 0.951 & 26.6 & 13500 \\
\hline Minimum & & 0.860 & 17.7 & 6400 \\
\hline Maximum & & 1.024 & 52.0 & 19000 \\
\hline Standard Dev. & & 0.043 & 7.7 & 3000 \\
\hline Number Tested & & 62 & 62 & 62 \\
\hline Loaded Ignitor & 99-137 & & & \\
\hline Mean & & 0.997 & 25.0 & 16000 \\
\hline Minimum & & 0.951 & 15.3 & 7000 \\
\hline Maximum & & 1.026 & 54.8 & 23000 \\
\hline Standard Dev. & & 0.020 & 9.4 & 4000 \\
\hline Number Tested & & 39 & 39 & 39 \\
\hline Explosive Subassembly & i0-19 & & & \\
\hline Mean & & 1.016 & 32.5 & 15000 \\
\hline Minimum & & 0.957 & 28.9 & 10000 \\
\hline Maximum & & 1.073 & 46.5 & 17000 \\
\hline Standard Dev. & & 0.044 & 5.3 & 2000 \\
\hline Number Tested & & 10 & 10 & 10 \\
\hline Explosive Subassembly & $20-79$ & & & \\
\hline Mean & & 1.009 & 36.3 & 14000 \\
\hline Minimum & & $0 . \$ 11$ & 25.7 & 8000 \\
\hline Maximum & & 1.083 & 59.8 & 18000 \\
\hline Staridard Dev. & & 0.056 & 9.6 & 3000 \\
\hline Number Tested & & 13 & 13 & 13 \\
\hline
\end{tabular}

Table 7. (cont)

\begin{tabular}{|c|c|c|c|c|}
\hline Item Teuted & $\begin{array}{l}\text { Group } \\
\text { Serial } \\
\text { Number }\end{array}$ & $\begin{array}{c}\mathbf{R}_{0} \\
\text { (abman) }\end{array}$ & $\begin{array}{l}\text { Thece } \\
\left({ }^{\circ} \mathrm{C}\right)\end{array}$ & $\begin{array}{l}\text { Gamma } \\
\left(6 \mathrm{~W} /{ }^{\circ} \mathrm{C}\right)\end{array}$ \\
\hline Exploaivo 8ubenembly & $10-133$ & & & \\
\hline Mecen & & 0.987 & 33.3 & 16190 \\
\hline Minimum & & 0.867 & 21.7 & 6000 \\
\hline Maximum & & 1.078 & 71.9 & 21900 \\
\hline Standard Dev. & & 0.040 & 9.8 & 3400 \\
\hline Number Teated & & $\pi 7$ & 77 & 77 \\
\hline Detonator Subeasembly & $70-79$ & & & \\
\hline Moan & & 1.068 & 32.8 & 16000 \\
\hline Minimum & & 0.927 & 27.5 & 14500 \\
\hline Maximum & & 1.113 & 374 & 18900 \\
\hline Standard Dev. & & 0.060 & 3.4 & 1400 \\
\hline Number Teated & & 8 & 8 & 8 \\
\hline Detonator Subeseembly & $92-107$ & & & \\
\hline Mean & & 1.046 & 40.8 & 14000 \\
\hline Minimum & & 1.010 & 29.1 & 7000 \\
\hline Maximum & & 1.074 & 73.0 & 18000 \\
\hline Standard Dev. & & 0.027 & 16.3 & 4000 \\
\hline Number Tested & & 9 & 9 & 9 \\
\hline
\end{tabular}

When tested at room temperature after exposure to combined environments unit 108 exhibited a high bridgewirt resistance after thermal shock (Table 8).

Table 8. Bridgewire Resistance History of Unit 108

\begin{tabular}{lcc}
\multicolumn{1}{c}{ Assembly Stage } & $\begin{array}{c}\text { Date } \\
\text { Recorded }\end{array}$ & $\begin{array}{c}\text { Resistance } \\
\text { (ohms) }\end{array}$ \\
\hline Bare Wire & $5 / 5 / 81$ & 0.997 \\
Ignitor & $6 / 8 / 81$ & 0.996 \\
Explosive Subassembly & $6 / 11 / 81$ & 1.005 \\
After Thermal Shock & $7 / 27 / 81$ & 1.204 \\
After Mechanical Shock & $7 / 30 / 81$ & 1.058 \\
After Vibration & $8 / 3 / 81$ & 1.059 \\
\hline
\end{tabular}

The resistance readings will normally increase at the explosive subassembly stage due to the increased lead length required to attach the connector. The resistance after thermal shock is higher than expected and may reflect a damaged bridgewire or a poor bridgewire weld. The unit had a comparatively short ignition time compared to units in the ambient group, which might suggest a "hot spot" in the wire due to 
damage. The open time for this unit agrees with the other units in the group. The weld process should be reviewed.

\section{Detonator Output Studles}

The MC3644 has a 1-mm standoff from the HNSIIA ALMDF in the next assembly. The purpose of the gap is twofold:

1. It prevents any low-level preshock which originates in the DDT column and travels through the steel body ahead of the detonation from entering the HNS-IIA ALMDF, compressing the HNS-IIA ALMDF core and thereby decreasing its sensitivity. Computer modeling by J. Harlan has shown that preshock exists and that it will arrive in the HNS-IIA ALMDF ahead of the main detonation wave. The preshock amplitude is approximately 0.5 to $0.8 \mathrm{GPa}$. The exact effect of preshock on the HNS-IIA ALMDF detonation sensitivity is not understood. The approach is to isolate the detonator to prevent preshock.

2. The 10-grain/ft HNS-IIA ALMDF is large enough in terms of explosive diameter to be side-initiated through its aluminum sheath. However, the sheath is not strong enough to support forces imposed by the detonator in contact with it for $20 \mathrm{yr}$. Tolerances in the assembly would not allow a zero-standoff zero-contact assembly.

Therefore, the assembly was designed to hold the detonator $1.0 \mathrm{~mm}$ above the HNS-IIA ALMDF and to use the detonator steel closure disc as a fiying plate to initiate detonation in the HNS-IIA ALMDF. The pressure threshold for HNS-IIA ALMDF ${ }^{9}$ and for other explosives, ${ }^{10}$ is dependent on particle size, pulse width, density and geometry. For a 35-ns pulse width, coarse powder requires a higher shock pressure at a given density and geometry than does fine powder.

HNS-IIA ALMDF begins as a coarse $\left(<0.5 \mathrm{~m}^{2} / \mathrm{g}\right)$ powder; however, it undergoes somewhat severe mechanical deformation during manufacture which causes the particles to break. Particle-sized measurements by R. Jungst ${ }^{11}$ indicates an order of magnitude size reduction. The effect of this size reduction on sensitivity, particularly in HNS-IIA ALMDF where geometry would be a significant parameter, is not known. The available data indicate that the pressure threshold for pelletized HNS-IIA ALMDF at $1.60 \mathrm{Mg} /$ $\mathrm{m}^{3}$ density and a $35-\mathrm{ns}$ pulse width is $8.6 \mathrm{GPa},{ }^{11}$ and that this wculd appear to be the worst case. To achieve 8.6 GPa in the HNS-IIA ALMDF, the steel closure disc would be required to have a minimum velocity of
$1.8 \mathrm{~km} / \mathrm{s}$, acuming planar impact. In the provent MC3644 design, the clowure dise is $0.127 \mathrm{~mm}$ thick. The prescure pulee width into the HNS-IIA AIMDP in the MDF as calculated by a computor model' wing $\mathrm{CSQ}^{12}$ is lese than $30 \mathrm{~ns}$.

To determine the MC3644 diac velocity at 1.0-mm displacement, a number of output subanemblies were fabricated without ignitons. Ignitors were in limited supply; thereiore in Shots 1, 2, and 3 (Table 8) an RP87 exploding bridgewire detonator was ued to initiate the DDT column in the output subasembly to full detonation (Figure 6). VISAR (Velocity Interferometer System for Any Reflector) techniques were used to determine the insta itaneous diac velocity. The output charge parameters and the results are shown in Table 9. The DDT column and output charge are the same diameter. Typical VISAR data illustrating velocity and displacement histories for discs $0.13 \mathrm{~mm}$ and $0.25 \mathrm{~mm}$ thick are shown in Figure 7.

The results for Shot 4 (Table 9) represent the average for three shots in which MC3644s of the WR version were tested for disc velocity. The discs were $0.13 \mathrm{~mm}$ thick. The velocity of $2.93 \mathrm{~km} / \mathrm{s}$ compares with that obtained in Shot 2 . It does not appear that RP87 affected the disc velocity in Shot 2. The VISAR velocity and displacement histories for Shot 4 are shown in Figure 8.

The Gurney equation for calculating the velocity of a metal plate in an open-face sandwich geometry ${ }^{13}$ svas used to obtain an estimate of the closure disc velocity. A Gurney characteristic velocity $(\sqrt{2 E})$ of $2.41 \mathrm{~km} / \mathrm{s}^{14}$ was used for the $\mathrm{CP}$ output change which has a density of $1.75 \mathrm{Mg} / \mathrm{m}^{3}$. The calculated velocities for $0.13 \mathrm{~mm}$ and $0.25 \mathrm{~mm}$ closure discs were $2.84 \mathrm{~km} / \mathrm{s}$ and $2.19 \mathrm{~km} / \mathrm{s}$, respectively. In this calculation, the mass of explosive included both the output charge and the DDT column. When only the mass of the output charge was considered, the calculated velocities were $33 \%$ lower; this indicates that the DDT column makes a significant contribution to the disc velocity. A comparison of the disc velocities of Shots 1 and 2 suggests that the output charge should be as long as possible.

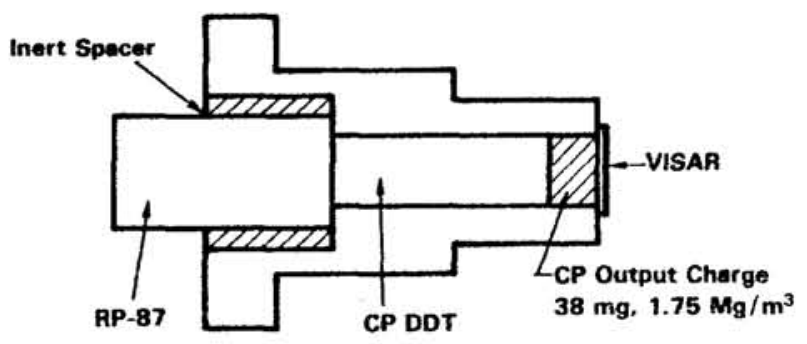

Figure 6. Assembly for Closure-Disc Velocity Measurement 


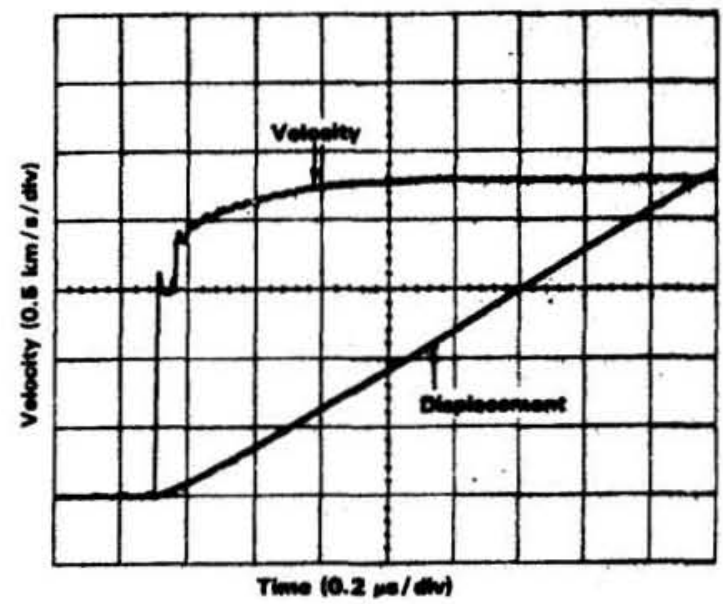

๑. $0.28 \mathrm{~mm}$ Diese

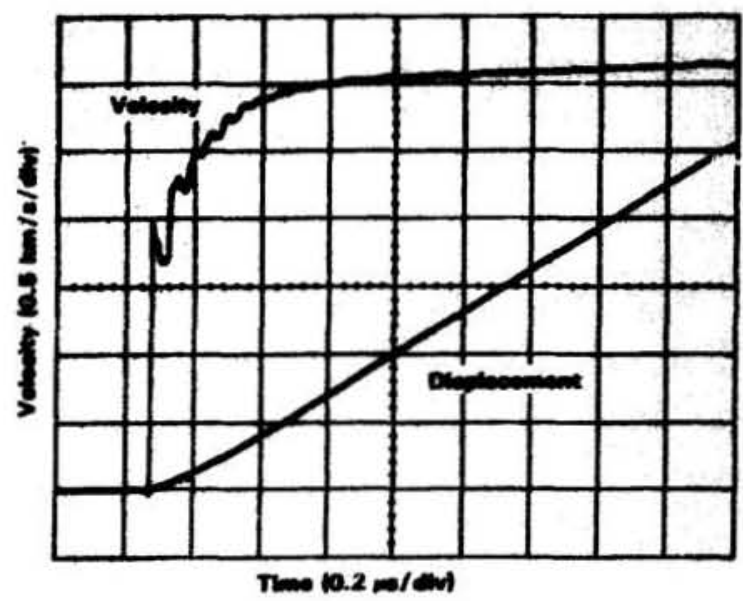

b. $0.13=0$ Dee

Flgure 7. Typical Cloeure-Diac Velocity and Dieplacoment Histories

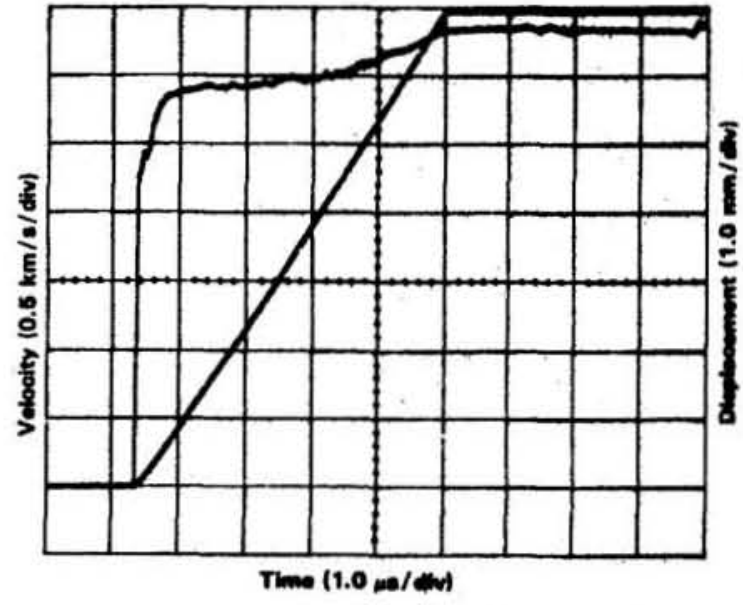

-

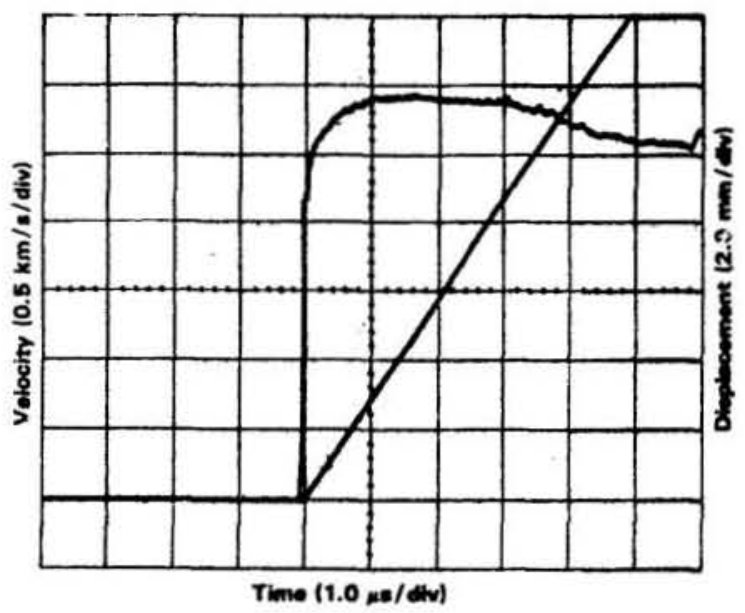

b
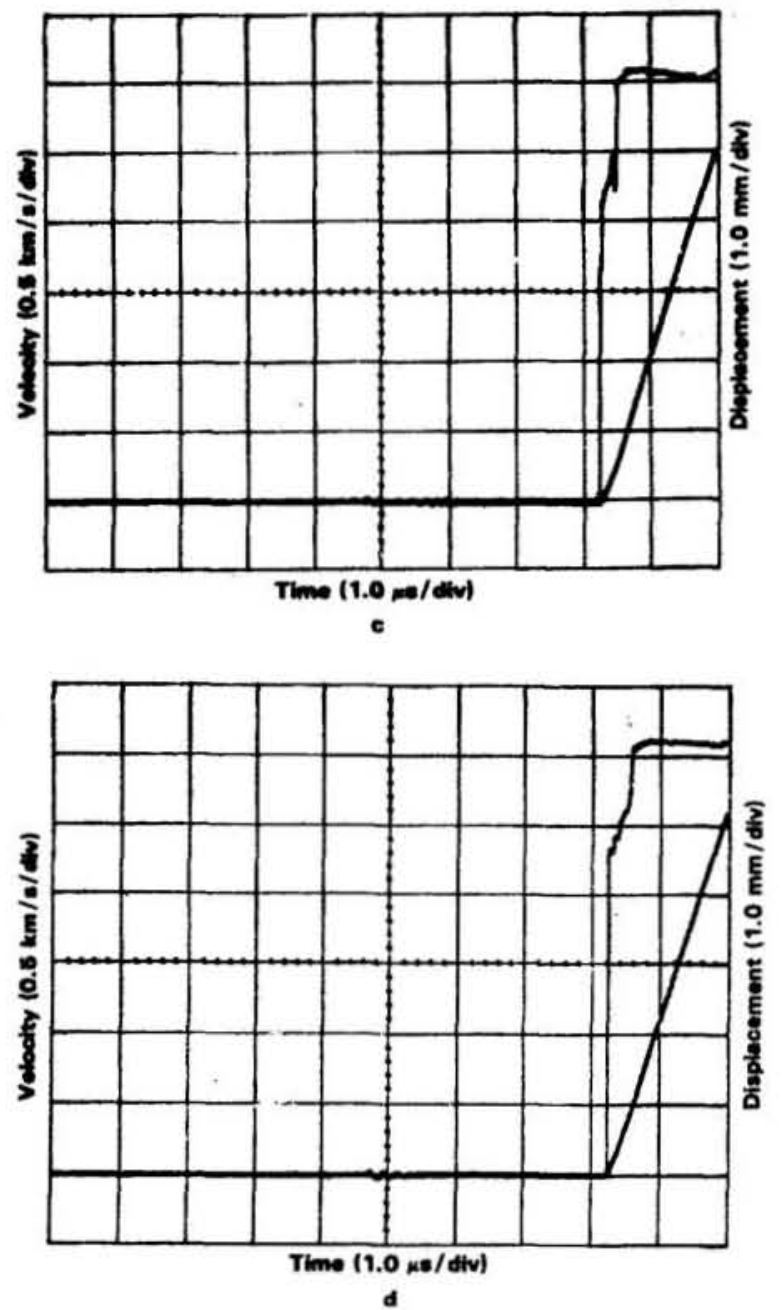

Figure 8. Closure-Disc Velocity and Displacement Histories for MC3644 WR Detonator With 0.13-mm-Thick Disc 


\section{Table 9. Output Charge Paramotors and Cloaure Diec Velaclty Data at Room Temperature (Velocity at 1.0-mm Dieplacement)}

\begin{tabular}{cccccccc} 
& & & \multicolumn{2}{c}{ Charge } & DDT & Diac & $\begin{array}{c}\text { Diac } \\
\text { Shot }\end{array}$ \\
\cline { 4 - 5 } & Unit & $\begin{array}{c}\text { Diameter } \\
(\mathbf{m m})\end{array}$ & $\begin{array}{c}\text { Length } \\
(\mathbf{m m})\end{array}$ & $\begin{array}{c}\text { Weight } \\
(\mathbf{m g})\end{array}$ & $\begin{array}{c}\text { Length } \\
(\mathbf{m m})\end{array}$ & $\begin{array}{c}\text { Velocity } \\
(\mathbf{k m} / \mathbf{s})\end{array}$ & $\begin{array}{c}\text { Thickness } \\
(\mathbf{m m})\end{array}$ \\
\hline 1 & 42 & 3.30 & 1.27 & 19 & 7.24 & 2.75 & 0.13 \\
2 & 57 & 3.30 & 2.54 & 38 & 5.97 & 2.90 & 0.13 \\
3 & 52,54 & 3.30 & 2.54 & 38 & 9.10 & 2.05 & 0.25 \\
4 & $15,13,10$ & 3.30 & 2.54 & 38 & 9.10 & 2.93 & 0.13 \\
\hline
\end{tabular}

The VISAR records for Shot 4 (Figure 8) indicate that the closure dises did not accelerat: as uniformly as did those in Shots 1, 2, and 3 (Figure 7). The scale factors are the same in both cases. The reason for this difference is not understood. The intensity, contrast, and data traces from the VISAR records do not indicate experiment setup, disc surface preparation, or computational problems.

The effects of output charge length, DD'T column length and density, and closure disc thickness should be investigated further. Increasing the disc thickness from 0.127 to $0.254 \mathrm{~mm}$ would double the pressure pulse width and would be beneficial if the disc velocity remained greater than $2.0 \mathrm{~km} / \mathrm{s}$. The calculated ${ }^{11}$ pressure pulse driven into the HNS-IIA ALMDF by a 0.127 -mm-thick disc at a velocity of $2.2 \mathrm{~km} / \mathrm{s}$ is approximately $15.0 \mathrm{GPa}$.

Flash radiography should be used to determine the shape and mechanical integrity of the closure disc.

\section{Faillure Investigation}

During feasibility testing at $-34^{\circ} \mathrm{C}$, one MC3644 ID (Unit 14) failed to initiate the HNS-IIA ALMDF. It had been agreed that functional-rejected ignitor headers from the MC3423 development could be used for feasibility tests. Some of these functional rejects had hairline cracks in the ceramic substrate. Postmortem of the detonator by UPI showed that the DDT column did not grow to detonation. A comparison of the output body inside diameters of the failed unit and a successful unit is illustrated in Figure 9.

Further investigation revealed that the ETR gamma value for the ignitor in the failed unit decreased from $16,000 \mu \mathrm{W} /{ }^{\circ} \mathrm{C}$ after loading to $10,000 \mu \mathrm{W} /{ }^{\circ} \mathrm{C}$ after the ignitor assembly was welded into the output body subassembly. This change in gamma is indicative of a decoupling of the $\mathrm{CP}$ and bridgewire. During the ignitor assembly, a compressive force of $489 \mathrm{New}-$ tons is applied between the ignitor and output body to insure contact of the ignitor output and DDT column input surfaces. In addition to the change in gamma, several ignitors which had been loaded with the feasibility units, but not used, were found to have a contaminant on the CP. This contaminant was a silicon grease which was used to seal the covers of desiccated containers. How these units became contaminated with this grease is not known.

Table 10 summarizes a series of 16 test firings conducted in an effort to duplicate the failure. Various possible failure mechanisms were incorporated into the units. These included

- Cracked headers

- Contaminants such as water, silicon grease, and isopropyl alcohol in the CP

- Excess free volume

- Output bodies without closure disc

Except for the contaminants, these failure mechanisms were intended to show that a sudden decrease in pressure at the ignitor/DDT column interface may have been the cause of the failure. All of these units were fired successfully. The excess free volume test in which a small hole is drilled into the side of the ignitor has not been performed.

It is still felt that a cracked header was the cause of the failure. The $10,000 \mu \mathrm{W} /{ }^{\circ} \mathrm{C}$ gamma, per se, is not sufficient to cause the failure. CP detonators with gammas as low as $\mathbf{3 0 0 0}$ have fired. However, if the decrease in gamma was caused by a crarked header which failed structurally at assembly, it is possible that complete failure occurred shortly after ignitiondropping the pressure behind the burn front and extinguishing the reaction. The isopropyl alcohol contaminant caused the CP to swell and made the units totally unusable. The cause of this failure should be determined to aid in future header designs intended for use in DDT devices. 


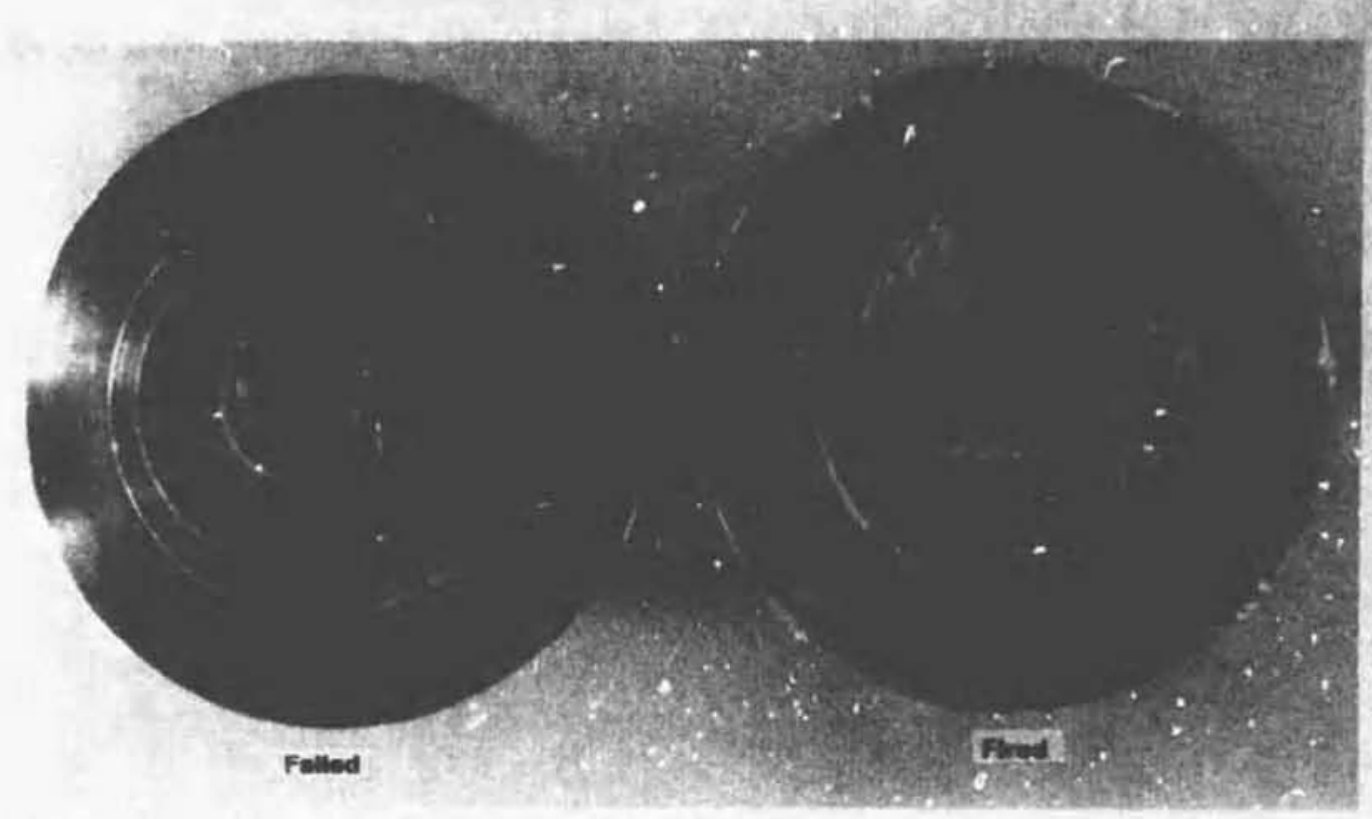

Figure 9. Comparison of Fired and Failed MC3644 ID Detonators

Table 10. MC3644 ID Fallure Analysis Test Data

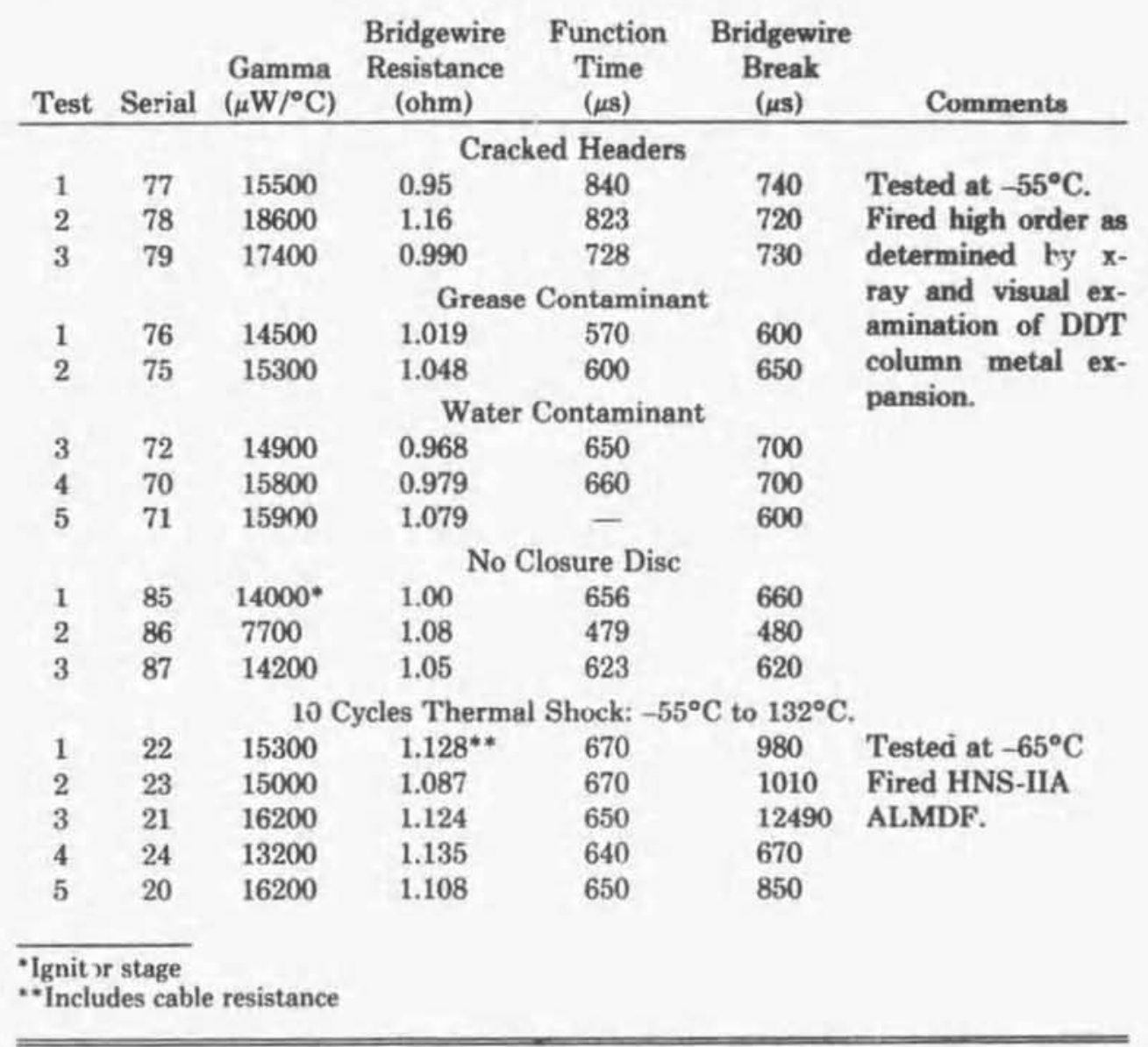




\section{MC3644 WR Detonator}

The major difference between the interim and WR or final design MC3644 is the header (Figure 4). The number of pieces has been reduced from three to two, the number of assembly bonding steps from four welds plus one solder connection to three welds (not including the bridgewire weld). The ignitor and electrical leads are in one part. The ctrical connector is machined separately to reduce the cost of broaching the inside grooves. This also should reduce the cost of the brazed header.

\section{Header and Ignitor Design and Deveiopment Status}

The ceramic header is being manufactured by VELER, Inc, Santa Clara, California, on Contract 616817. The header and electrical shells are fabricated from Kovar. The ceramic is supplied by Mound Laboratory in the bisque state. Comments made by VELER indicate that the Diamonite ceramic produces a better header than other ceramics because the chromium in the Diamonite ceramic gives better metallizing adhesion. The Mound bisque is isostatically pressed, and as a result the shrinkage is less and more uniform. The fact that VELER can machine the bisque is an advantage in that they have better control over the parts. Equally important, the lead times for procuring ceramic parts for metallizing is considerably less -6 to $8 \mathrm{wk}$ from the bisque stage as compared to 15 to 20 wk from other sources.

The fabrication process involves core-drilling blanks from the bisque stock. At the present time, the percentage of waste is high; it would be reduced if the bisque bar diameter were increased to $38.1 \mathrm{~mm}$.

Six headers were subjected to a $276 \mathrm{MPa}$ (40k psi) loading test. Subsequently, the headers were cleaned and sectioned; no cracks were found and no significant voids were found in the braze joints.

UPI has completed bridgewire, connector assembly, and header-to-output body weld studies and loading studies on the new hearier.

The CP explosive is loaded into the header in two parts of $17.5 \mathrm{mg}$ each. The first part is loaded at 276 $\mathrm{MPa}(40 \mathrm{k}$ psi) and the second at $69 \mathrm{MPa}$ (10k psi).

Forty ignitors were assembled for subsequent testing and delivery to SNLA. The ETR data recorded at three stages of assembly are summarized in Table 11. The gamma values are $29 \%$ higher than for the interim units in Table 1. Six trainers and ten MC3644 WR detonators have been shipped to SNLA for use in FTU system test series.

\section{Tablo 11. Electrothermel newponse Tat Reeults on Development Lot A of ceses WR Dotunator}

\begin{tabular}{|c|c|c|c|}
\hline Parameter & $\begin{array}{c}\text { Bare } \\
\text { Bridge }\end{array}$ & Ignitor & Pinal \\
\hline \multicolumn{4}{|c|}{ Bridge Resistance (ohms) } \\
\hline Average & 0.991 & 1.003 & 1.006 \\
\hline Minimum & 0.911 & 0.938 & 0.942 \\
\hline Maximum & 1.060 & 1.062 & 1.066 \\
\hline Standard Deviation & 0.044 & 0.037 & 0.057 \\
\hline Number Tested & 39 & 31 & 31 \\
\hline \multicolumn{4}{|l|}{$\operatorname{Gamma}\left(\mu \mathrm{W} /{ }^{\circ} \mathbf{C}\right)$} \\
\hline Average & 860 & 21,000 & 21,500 \\
\hline Minimum & 710 & 15,600 & 15,800 \\
\hline Maximum & 1160 & 25,100 & 25,700 \\
\hline Standard Deviation & 90 & 2,500 & 2,500 \\
\hline Number Tested & 39 & 31 & 31 \\
\hline
\end{tabular}

\section{Ignitor No-Fire Sensitivity}

The size, geometry, and materials, including the bridgewire design, ${ }^{*}$ are patterned after the MC3423 Detonator for which ignition and no-fire sensitivities have been demonstrated and reported. Since the nofire sensitivity is very crucial in the MC3644 application, a 10-unit Langlie sensitivity test was completed to verify that no change in sensitivity has occurred. ASENT computer program analysis shows that a $95 \%$ confidence level, 1 unit in 1000 would be expected to fire at $1.28 \mathrm{~A}$. The $50 \%$ threshold was $1.46 \mathrm{~A}$ with a standard deviation of $0.228 \mathrm{~A}$. The results show that no significant changes have occurred and that the nofire requirement of $1.0 \mathrm{~A}$ can be met easily. A probability plot of the no-fire test results is included in Figure 10.

\section{Functional Proof Test}

Nine WR design detonators were assembled and subjected to 10 consecutive cycles of thermal shock from $-54^{\circ} \mathrm{C}$ to $132^{\circ} \mathrm{C}$. The units were held at each temperature for $2 \mathrm{~h}$. ETR and electrostatic susceptibility tests v'ore completed before temperature conditioning. ETR tests also were done following temperature conditioning. The nine units were assembled into a fixture with HNS-IIA ALMDF and test fired at $-54^{\circ} \mathrm{C}$, room temperature, and $100^{\circ} \mathrm{C}$-three units at each temperature, respectively.

\footnotetext{
*Alumina ceramic charge holder $3.05 \mathrm{~mm}$ deep x $3.05 \mathrm{~mm}$ diameter; $0.051 \mathrm{~mm}$ diameter Tophet $\mathrm{A}$ bridgewire
} 


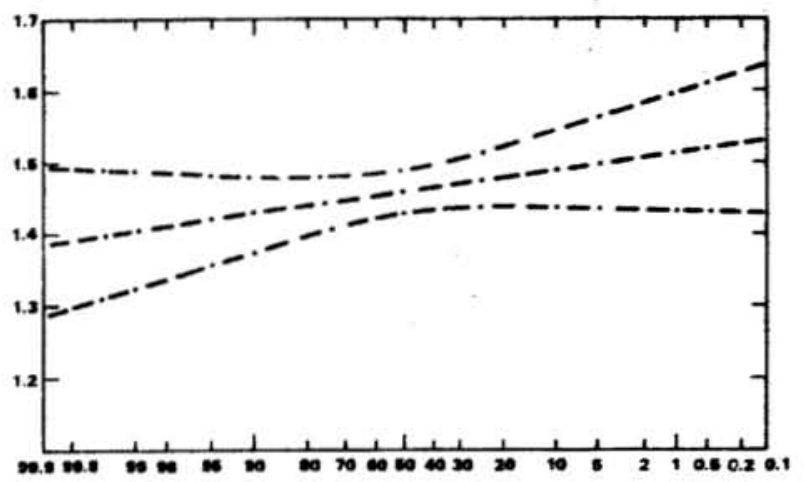

Figure 10. No-Fire Probability Curves for MC3644

The prethermal and postthermal shock ETR data for the nine units is summarized in Table 12. As a result of temperature conditioning, the average value for gamma decreased $23 \%$; there was a corresponding increase of $40 \%$ in the standard deviation. The range in gamma values increased from 9.000 to 12,900 . It is not clear that this change was due to the temperature conditioning. The nine units were run through the ETR test twice after thermal conditioning. The first time the average gamma was greater than 30,000 , which is not realistic. The average in Table 12 is the result of the second run, which was done $24 \mathrm{~h}$ later. The raw ETR data is being reviewed by UPI for possible test procedure problems.

Table 12. Prethermal and Postthermal Shock for Electrothermal Response Data for MC3644 WR Functional Proof Test

\begin{tabular}{lcc} 
& Standard \\
Parameter Average & Dev. & Minimum Maximum \\
\hline
\end{tabular}

\begin{tabular}{lcccr} 
& \multicolumn{3}{c}{ Bridge Resistance (ohm) } \\
\cline { 2 - 4 } $\begin{array}{l}\text { Prethermal } \\
\text { Shock }\end{array}$ & 1.012 & 0.042 & 0.977 & 1.057 \\
$\begin{array}{l}\text { Post thermal } \\
\text { Shuck }\end{array}$ & 1.013 & 0.043 & 0.950 & 1.064 \\
Change & 0 & 0 & -2.7 & +0.06
\end{tabular}

\begin{tabular}{lcccc}
$\begin{array}{l}\text { Prethermal } \\
\text { Shock }\end{array}$ & 22000 & 3000 & 16000 & 25000 \\
$\begin{array}{l}\text { Postthermal } \\
\text { Shock }\end{array}$ & 17000 & 4000 & 12000 & 25000 \\
$Y$ Change & -23 & +40.7 & -21.9 & +1.96 \\
\hline
\end{tabular}

The gamma for MC3644 ID unitu decreaed 8.4\% after thermal shock (Table 5) and 14.3\% after mochanical shock and vibration.

The destructive teet fire data are given in Table 13. The data met all requirements for the MCss4.

Table 13. Mcse44 WA rroof Teet Data (After f nermal shock $-55^{\circ} \mathrm{C}$ to $132{ }^{\circ} \mathrm{C}, 10$ cycles)

Temper-

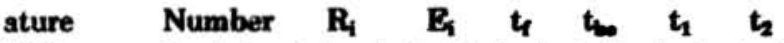
( $\left.{ }^{\circ} \mathrm{C}\right)$ Tested (ohms) (mJ) (ns) (ns) (ns) (ns)

\begin{tabular}{llllllll}
\hline Amb & 3 & $\frac{1.16}{0.02}$ & $\frac{15.7}{1.7}$ & $\frac{608}{5}$ & $\frac{1150}{210}$ & $\frac{6.91}{0.26}$ & $\frac{7.11}{0.35}$ \\
$-55^{\circ} \mathrm{C}$ & 3 & $\frac{1.10}{0.13}$ & $\frac{18.4}{2.8}$ & $\frac{777}{67}$ & $\frac{1150}{46}$ & $\frac{6.88}{0.07}$ & $\frac{7.04}{0.04}$ \\
$100^{\circ} \mathrm{C}$ & 3 & $\frac{1.10}{0.02}$ & $\frac{13.5}{0.4}$ & $\frac{540}{1}$ & $\frac{1030}{120}$ & $\frac{6.93}{0.05}$ & $\frac{7.06}{0.02}$
\end{tabular}

Note:

$R_{i}=$ Bridgewire resistance at ignitor

$E_{i}=$ Ignition energy

$t_{i}=$ Function time

$t_{b_{0}}=$ Bridgewire open time

$\mathrm{t}_{1}, \mathrm{t}_{2}=$ HNS-IIA ALMDF transit time

*Number above each line is the average and number below line is standard deviation.

There is some interest in studying the relationship of gammas as measured in the ETR test and the dynamic functional characteristics. Figures 11 and 12 illustrate the relationship of function time and gamma for the MC3644 ID combined environment group and the MC3644 WR proof test group. About the only conclusion one can draw from these few data is that, although there is a trend toward longer times with higher gammas, there are also unexplainable anomalies. Function time is used in this comparison because ignition time, which might give different results, is not being calculated correctly by the CCDS: it is calculated to be longer than the function time. In an earlier component (MC3095) in which titanium subhydride potassium perchlorate was loaded on the bridgewire and ceramic header, there was no correlation between gamma and ignition time.

This is not to suggest that ETR nondestruct testing is not of value, because it is. Bad welds, decoupled powder, powder and wires, and contamination of the 
powder can be detected. The ETR data cannot be used to predict which units will have long or short function times, however.

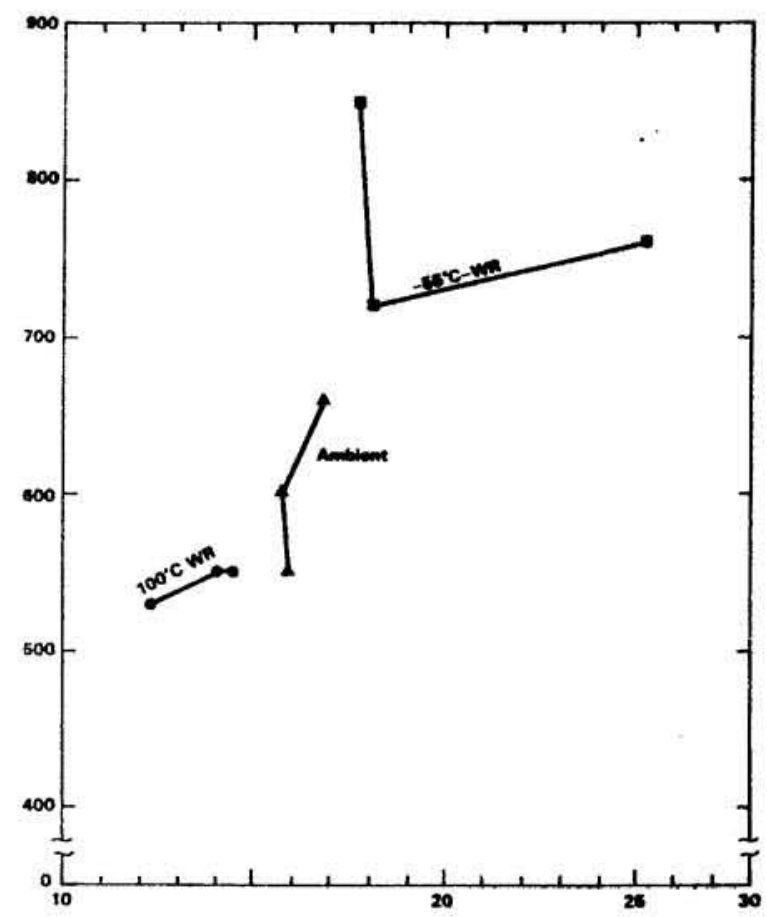

Figure 11. MC3644 ID Function Time as a Function of Gamma

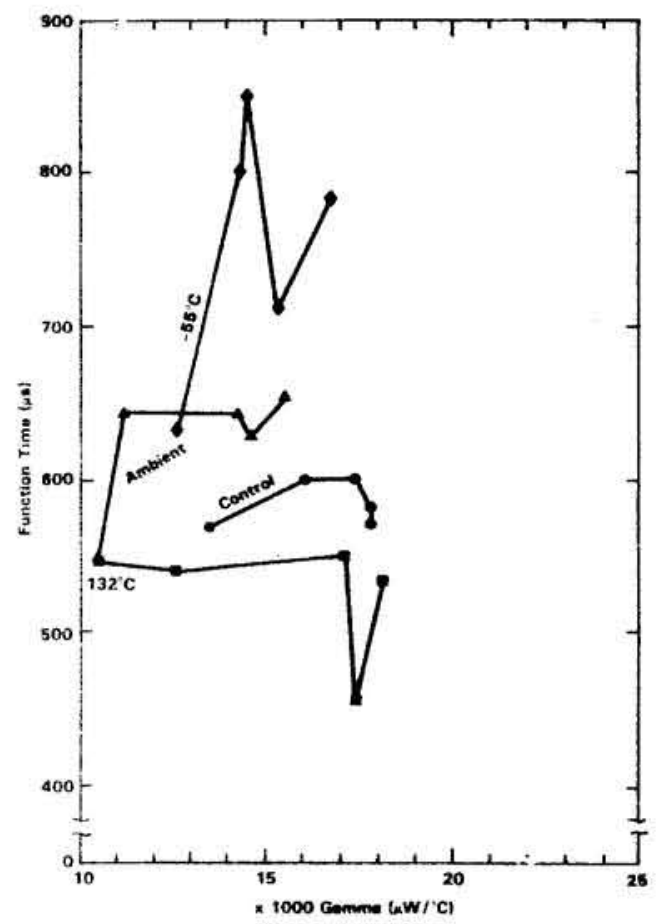

Figure 12. MC3644 $W^{\prime} R$ Function Time as a Function of Gamma

\section{MC3644 Deaign \\ Verfification Pian}

Design verification testing at UPI will include the following:

- Fabrication of 158 units

- ETR and BSD nondestruct teeting

- Ship 30 to SNLA

Perform the following destructive tests:

- 20 units Langely no-fire

- 63 units all-fire regression analysis

- Subject 45 units to combined environments per PS318493 and D-test 15 each at room temperature, $-55^{\circ} \mathrm{C}$, and $100^{\circ} \mathrm{C}$, reepectively

Most of the hardware for this series of tests is on hand.

\section{Deliveries and Schedules}

\section{Dellveries}

Delivery of units to meet system test needs is on schedule. Fifty MC3644 IDs were received from UPI. Ten additional MC3644 IDs have been ordered. The MC3644 ID has been designated for use in the Bomb Test Unit (BTU) and Parachute Development Unit (PDU).

Ten MC3644 WR detonators were received along with six trainers. These units have been designated for use in the FTU test program only.

\section{Schedules}

The development and Phase II production activities at UPI are defined by PERT Network ND 318493. A summary of these activity peg points is shown in Figure 13. The development program is on schedule.

\section{Action Items}

The development program at UPI is presently on schedule; however, the following items will require timely attention to maintain the schedule for first production unit delivery in March 1983.

- An Advance Engineering Release (AER) for the deionator should be issued as soon as UPI has assembled the design verification lot. An AER for the header has been issued.

- The drawings should be transferred to Mound

- The velocities of the 0.13 - and $0.25-\mathrm{mm}$ closure dises must be determined. The closure disc 
thickness should be changed to $0.25 \mathrm{~mm}$, provided the velocity is high enough.

- The effects of DDT column length and denaity and output column length on disc volocity should be evaluated.

- The calculation of ignition time by CCDS is not correct. The ignition model needs to be reviewed.

- The ETR test procedure should be evaluated. The gamma values obtained for a given unit at different times are varying over unrealistic ranges.

- The cause for the failure (discussed earlier) should be determined.

- Test fixtures and instrumentation need to be defined and procured for production lot acceptance testing of the MC3644 at UPI.

- The bridgewire welding process at UPI should be reviewed to eliminate possible bridgewire damage.

\section{Reforences}

1A. K. Jecobeon, Development of a Mild Detonating Fuze Acsembly, 8AND81-2500 (Albuquerque: Sandia National Laboratories, to be publiahed).

2 W. Flemming, J. W. Fronabargar, and J. Q. Seancy, "Preparation of 2-(5-Cyanotetraeolato) Penta-Ammine-Cobelt (III) Perchlorate, CP, a Now Material for Detonetor Applicationa," Am. Def. Prop. Amen. Mite, Materials and Procesaing Diviaion, Albuquerque, NM, May 15-17, 1979.

${ }^{3}$ M. L. Lieberman and J. L. Fronebaryer, "Status of the Development of 2-(5-Cyanoterrazolato) Penta-Ammine-Cobalt (III) Perchlorate for DDT Devices," Presented at Seventh International Pyrotechnica Seminar Vail, CO, July 14 $18,1980$.

4J. Q. Searcy and K. L. Shanahan, Thermal Decomposition of the New Exploeive 2-(5-Cyanotetrazolato) PentaAmmine-Cobalt (III) Perchlorate, SAND78-0466 (Albuquerque: Sandia Laboratories, Auguat 1978).

${ }^{5}$ Development Test Report on the MC3423, UPI DTR128, Contract 13-3148, (Phoenix: Unidynamics/Phoenix, Inc, 23 June 1980).

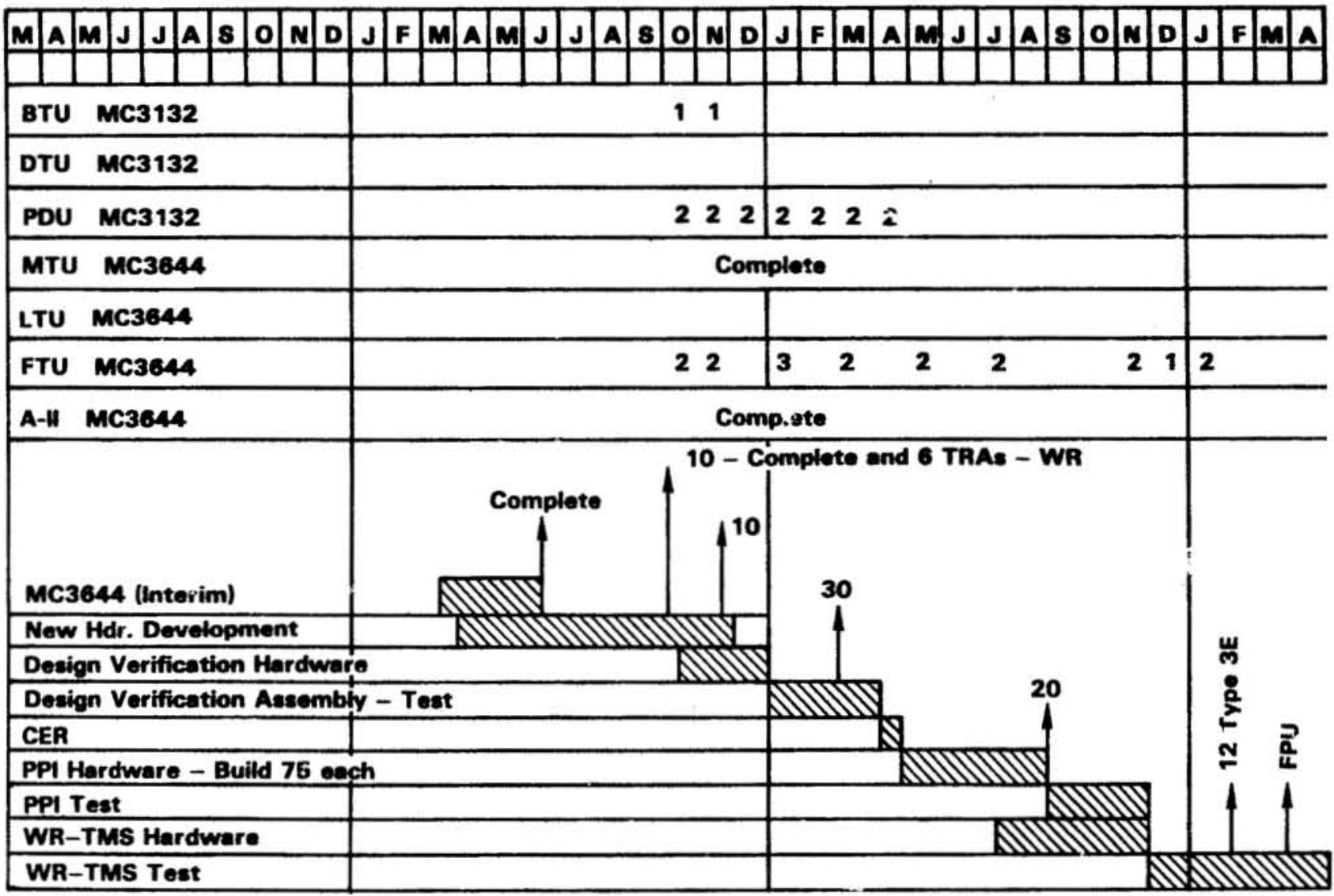

Figure 13. MC3644 WR Development and Phase IV Production Schedules 
${ }^{6}$ M. L. Liebernan, Activation of the deflagration-toDetonation Transition Project: Quarterly Report for the Period September Through November 1978, 8AND79-0837 (Albuquerque: Sandia National Laboratories, May 1979).

${ }^{7}$ M. L. Lieberman, Deflagration-to-Detonation Transition Project: Quarterly Report for the Period September Through November 1979, SAND80-1157 (Albuquerque: Sandia National Laboratories, July 1980).

${ }^{8}$ R. C. Prew, Development Report UA1538 Calculator Controlled Data System, SAND78-0512 (Albuquerque: Sandia National Laboratories, September 1978).

${ }^{9}$ A. C. Schwarz, Study of Factors Which Influence the Shock Initiation Sensitivity of Hexanitrostilbene (HNS), SAND80-2372 (Albuquerque: Sandia National Laboratories, March 1981).

10A. C. Schwarz, Flyer Plate Performance and the Initiation of Insensitive Explosives by Flyer Plate Impact, SAND75-0461 (Albuquerque: Sandia National Laboratories, December 1975).

${ }^{11}$ R. G. Jungst, C-4 Trident Missile Body Ordnance Aging Gams Program Biannual Report for September 1980-February 1981, SAND81-2108 (Albuquerque: Sandia National Laboratories, November 1981).

${ }^{12} \mathrm{~S}$. L. Thompson, CSQII-An Eulerian Finite Difference Program for Two-Dimensional Material Response: Part 1, Material Selection, SAND77-1339 (Albuquerque: Sandia National Laboratorie3, May 1981).

${ }^{13} \mathrm{~J}$. E. Kennedy, Gurney Energy of Explosives: Estimation of the Velocity and Impulse Imparted to Driven Metal, SC-RR-70-790 (Albuquerque: Sandia National Laboratories, December 1970).

${ }^{14}$ P. L. Stanton, et al, Characterization of DDT Explosive, $C P$, The Seventh Symposium International on Detonation, US Naval Academy, Annapolis, MD, June 16-19, 1981, p 457. 


\title{
APPENDIX A
}

\section{DDT Detonators in Production}

\author{
Detonator \\ Weapon \\ MC3196A B61-3, -4; W85 \\ MC3423 W80 \\ MC3533 Development completed; cancelled \\ MC3608 W79 \\ MC3614 W84
}




\section{APPENDIX B}

\section{Hardware and Assembly Drawings for War Reserve MC3644}

\begin{tabular}{cl} 
No. & \multicolumn{1}{c}{ Title } \\
I & MC3644 \\
IA & MC3644 TRA \\
II & $\begin{array}{l}\text { Detonator Assembly } \\
\text { III }\end{array}$ \\
Output Assembly \\
BV & $\begin{array}{l}\text { Body Assembly } \\
\text { Body Output }\end{array}$ \\
& Disc \\
V & Ignitor \\
VI & Header Assembly, Bridged \\
& Bridge \\
VII & Header Assembly \\
& Connector Shell \\
VIII & Header \\
& Shell \\
& Insert, Ceramic \\
& Insert, Metallized \\
& Pin, Aft \\
& Pin, Foward \\
& Insert, Assembly
\end{tabular}

Dwg No.

318493

318494

346212

346211

346210

346209

345364

346234

346208

345354

346207

346206

346109

346107

346104

346105

346102

346103

346106 


\section{APPENDIX C \\ MC3644 Design Requirements}

\author{
All-Fire Current \\ Current Duration \\ No-Fire \\ Electrostatic Discharge \\ Capability \\ Pin to Case Isolation \\ Temperature \\ Thermal Cycle \\ Mechanical Snock \\ Vibration
}

5.0 A at $-55^{\circ} \mathrm{C}$

$7.5 \mathrm{~ms}$

$1.0 \mathrm{~A}, 5 \mathrm{~min}$ at room temperature

$20 \mathrm{kV}, 600 \mathrm{pF}$,

500 ohms

$>10$ ) $\mathrm{M} \Omega$ at $500 \mathrm{Vdc}$

$-55^{\circ}$ to $100^{\circ} \mathrm{C}$

10 Cycles, $-55^{\circ}$ to $100^{\circ} \mathrm{C}$

$390.0 \mathrm{~m} / \mathrm{3}^{2}, 1.5$ to $2.0 \mathrm{~ms}, 1 / 2$ sine

Sinusoidal, $98 \mathrm{~m} / \mathrm{s}^{2}, 26$ to $2000 \mathrm{~Hz}, 7.6$

mm double amplitude

Initiate 10 grain per foot HNS-IIA ALMDF. 


\section{APPENDIX D}

\section{MC3644 ID D-Test After Combined Environments*}

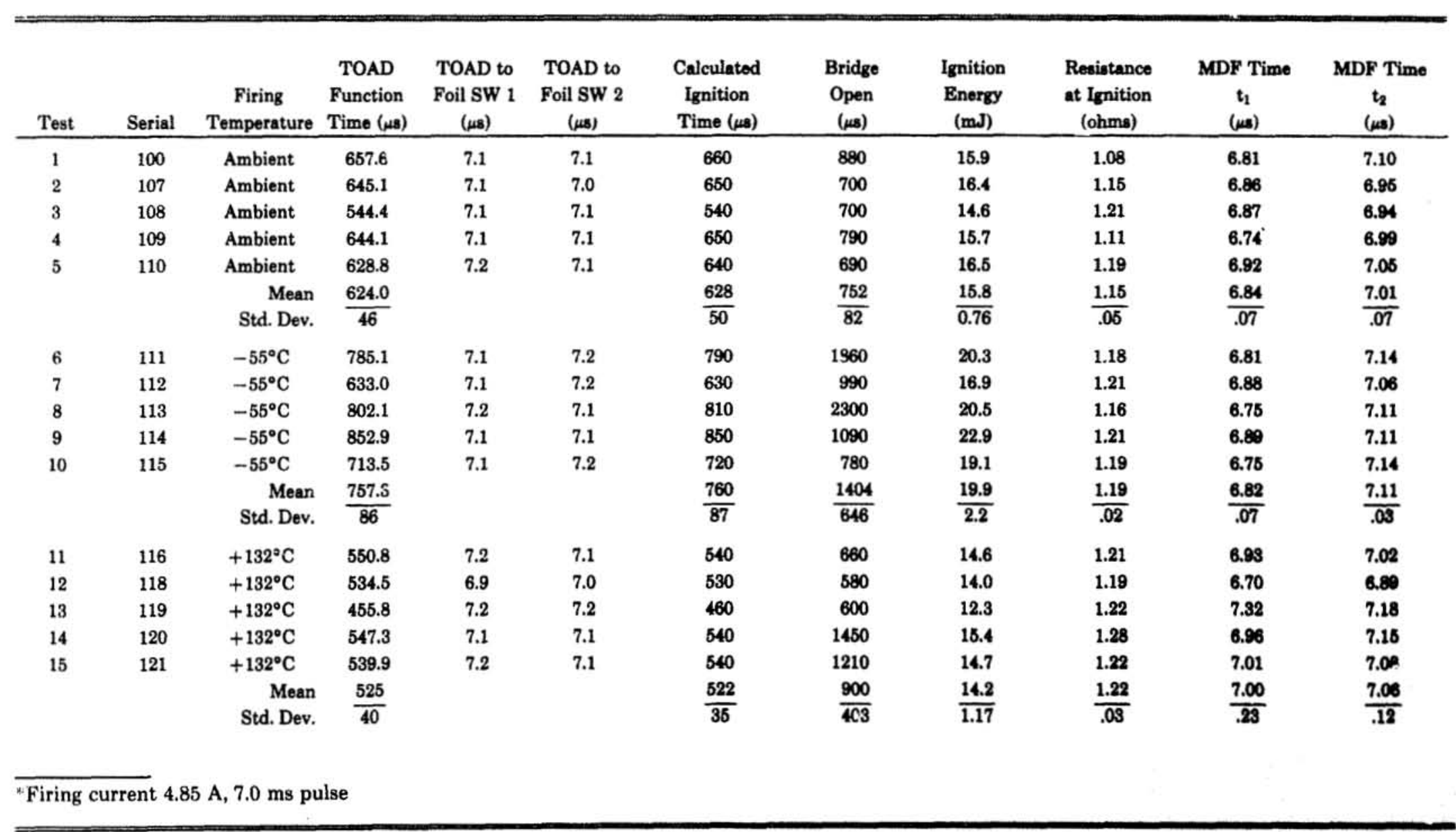




\section{DISTRIBUTION:}

\section{US Department of Energy}

Albuquerque Operations Office

PO Box 5400

Albuquerque, NM 87185

Monsanto Research Corp (5)

Mound Facility

PO Box 32

Miamisburg, OH 45342

Attn: R. A. Fischbein

P. L. Johnson

C. Brewer

E. E. Tibbitts

W. R. Henderson

Unidynamics/Phoenix, Inc (3)

PO Box 2990

Phoenix, AZ 85062

Attn: R. Smith

D. Fife

R. DeCoursey

\section{J. T. Hillman}

1415 R. R. Zottnick

2500 J. C. Crawford

2510 D. H. Anderson

2513 J. E. Kennedy (5)

2513 A. K. Jacobson (5)

2514 B. H. Van Domelen

2515 P. D. Wilcox

2516 W. G. Perkins

8150 J. L. Wirth

8151 C. N. Visbeck

8152 G. N. Beeler

8152 D. A. Clarin

8153 J. Wright

8214 M. A. Pound

3141 L. J. Erickson (5)

3151 W. L. Garner (3)

3154-3 C. H. Dalin (25)

For DOE/TIC (Unlimited Release) 